\title{
Extrasynaptic NMDA Receptors Couple Preferentially to Excitotoxicity via Calpain-Mediated Cleavage of STEP
}

\author{
Jian Xu, ${ }^{1}$ Pradeep Kurup, ${ }^{1}$ Yongfang Zhang, ${ }^{1}$ Susan M. Goebel-Goody, ${ }^{1}$ Peter H. Wu, ${ }^{2}$ Ammar H. Hawasli, ${ }^{3}$ \\ Matthew L. Baum, ${ }^{1}$ James A. Bibb, ${ }^{3}$ and Paul J. Lombroso ${ }^{1}$ \\ ${ }^{1}$ The Child Study Center, Yale University School of Medicine, New Haven, Connecticut 06520, ${ }^{2}$ Department of Psychiatry, University of Colorado Denver \\ School of Medicine, Aurora, Colorado 80045, and ${ }^{3}$ Department of Psychiatry, University of Texas Southwestern Medical Center, Dallas, Texas 75390
}

\begin{abstract}
NMDA receptor (NMDAR)-mediated excitotoxicity plays an important role in several CNS disorders, including epilepsy, stroke, and ischemia. Here we demonstrate the involvement of striatal-enriched protein tyrosine phosphatase (STEP) in this critical process. STEP $_{61}$ is an alternatively spliced member of the family that is present in postsynaptic terminals. In an apparent paradox, STEP $_{61}$ regulates extracellular signal-regulated kinase 1/2 (ERK1/2) and p38, two proteins with opposing functions; activated p38 promotes cell death, whereas activated ERK1/2 promotes cell survival. We found that synaptic stimulation of NMDARs promoted STEP ${ }_{61}$ ubiquitination and degradation, concomitant with ERK1/2 activation. In contrast, extrasynaptic stimulation of NMDARs invoked calpain-mediated proteolysis of $S T E P_{61}$, producing the truncated cleavage product $\mathrm{STEP}_{33}$ and activation of p38. The calpain cleavage site on STEP was mapped to the kinase interacting motif, a domain required for substrate binding. As a result, $\mathrm{STEP}_{33}$ neither interacts with nor dephosphorylates STEP substrates. A synthetic peptide spanning the calpain cleavage site efficiently reduced $\mathrm{STEP}_{61}$ degradation and attenuated p38 activation and cell death in slice models. Furthermore, this peptide was neuroprotective when neurons were subjected to excitotoxicity or cortical slices were exposed to ischemic conditions. These findings suggest a novel mechanism by which differential NMDAR stimulation regulates $\mathrm{STEP}_{61}$ to promote either ERK1/2 or p38 activation and identifies calpain cleavage of $\mathrm{STEP}_{61}$ as a valid target for the development of neuroprotective therapy.
\end{abstract}

\section{Introduction}

Glutamate excitotoxicity is an important component in the etiology of several neurological and neurodegenerative diseases (Lipton and Rosenberg, 1994; Arundine and Tymianski, 2003). Exposure to high levels of glutamate leads to overactivation of NMDA receptors (NMDARs) and influx of $\mathrm{Ca}^{2+}$, both of which disrupt normal intracellular signaling and contribute to neuronal cell death (Lipton and Rosenberg, 1994; Lipton, 1999). Despite the evidence implicating NMDAR activity in cell death, synaptic NMDAR activity is also implicated in neuronal survival and the development of synaptic plasticity (Malenka and Nicoll, 1993; Mabuchi et al., 2001; Xu et al., 2007). The mechanisms by which NMDAR activation lead to both prosurvival and proapoptotic pathways is an important question in neurobiology.

Recent studies on the differential stimulation of synaptic versus extrasynaptic NMDARs suggest some answers to this issue (Hardingham et al., 2002; Ivanov et al., 2006). Stimulation of

Received May 11, 2009; revised June 8, 2009; accepted June 15, 2009

This work was supported by the University of Texas Southwestern Gulf War Illness Research Program (J.A.B.), The National Association of Research on Schizophrenia and Depression, and National Institutes of Health Grants MH079710 and DA016672 (J.A.B.) and MH01527, MH52711, and DA017366 (P.J.L.). We thank Dan Austin and Drs. Steven Braithwaite, Janice Naegele, and Marilee 0gren for helpful discussions and critical reading of this manuscript and Kanehiro Hayashi for technical help with some experiments. We thank Drs. Chung and Huganir for the $\mathrm{pSer}{ }^{1480}$ NR2B antibody and Dr. Kansy for the C $\mathrm{dk} 5$ antibody.

Correspondence should be addressed to Dr. Paul J. Lombroso, Child Study Center, SHM I-270, Yale University School of Medicine, 230 South Frontage Road, New Haven, CT 06520. E-mail: paul.lombroso@yale.edu.

DOI:10.1523/JNEUROSCI.2212-09.2009

Copyright $\odot 2009$ Society for Neuroscience $\quad$ 0270-6474/09/299330-14\$15.00/0 synaptic NMDARs activates the Ras-extracellular signalregulated kinase (ERK)-cAMP response element-binding protein (CREB) pathway and translation of prosurvival proteins, such as BDNF (Hardingham et al., 2002; Vanhoutte and Bading, 2003; Léveillé et al., 2008; Mulholland et al., 2008). In contrast, activation of extrasynaptic NMDARs invokes proapoptotic proteins and suppression of survival pathways (Hardingham et al., 2002; Ivanov et al., 2006; Léveillé et al., 2008). Despite these advances, the precise pathways that regulate this process remain essentially unknown.

Striatal-enriched protein tyrosine phosphatase (STEP) is a brain-specific intracellular tyrosine phosphatase that antagonizes activity-dependent strengthening of synapses (Braithwaite et al., 2006). STEP isoforms are targeted to different intracellular compartments and are derived by alternative mRNA splicing. $\mathrm{STEP}_{46}$ is a cytosolic variant (Lombroso et al., 1991, 1993), whereas STEP $_{61}$ is a membrane-associated isoform that localizes to the endoplasmic reticulum and the postsynaptic terminal (Boulanger et al., 1995; Oyama et al., 1995; Bult et al., 1996). STEP members regulate important synaptic signaling proteins, including two members of the mitogen activated protein kinase (MAPK) family, ERK1/2 and stress-activated protein kinase p38 (Muñoz et al., 2003; Paul et al., 2003). It also regulates the Src kinase family member Fyn (Nguyen et al., 2002) and the NMDAR subunit NR2B (Snyder et al., 2005). STEP dephosphorylates ERK1/2, p38, and Fyn kinases at regulatory tyrosine residues within their activation loop, thereby inactivating them. In the case of NR2B, STEP dephosphorylation of Tyr ${ }^{1472}$ facilitates in- 
Table 1. Primary and secondary antibodies used in Western blots and immunofluorescence

\begin{tabular}{|c|c|c|c|c|c|}
\hline Antibody & Format & Immunogen & Host & Dilution & Source \\
\hline Anti-pERK1/2 & Whole IgG, unconjugated & Human synthetic phosphopeptide & Mouse & $1: 1000$ & Cell Signaling Technologies \\
\hline Anti-ERK2 & Whole IgG, unconjugated & C-terminus of rat sequence & Rabbit & $1: 5000$ & Santa Cruz Biotechnology \\
\hline Anti-p-p38 & Whole IgG, unconjugated & Human synthetic phosphopeptide & Rabbit & $1: 1000$ & Cell Signaling Technologies \\
\hline Anti-p38 & Whole IgG, unconjugated & C-terminus of mouse sequence & Rabbit & 1:1000 & Santa Cruz Biotechnology \\
\hline Anti-Fyn & Whole $\lg G$, unconjugated & Human synthetic phosphopeptide & Rabbit & $1: 600$ & Millipore \\
\hline Anti-pY ${ }^{1472}$ NR2B & Whole IgG, unconjugated & Synthetic phosphopeptide & Rabbit & $1: 1000$ & Phosphosolutions \\
\hline Anti-NR2B & Whole IgG, unconjugated & C-terminal of mouse NR2B & Rabbit & $1: 1000$ & Millipore \\
\hline Anti-GluR1 & Whole IgG, unconjugated & Rat synthetic peptide & Rabbit & 1:1000 & Millipore \\
\hline Anti-GABA $A(\beta 2 / 3)$ & $\lg \mathrm{G} 1$, unconjugated & Extracellular domain of $\beta 2 / 3$ & Mouse & $1: 1000$ & Millipore \\
\hline Anti-MAP2 & Whole IgG, unconjugated & Purified rat protein & Rabbit & $1: 2000$ & Millipore \\
\hline Anti-NR1 & Whole IgG, unconjugated & C-terminus & Mouse & $1: 600$ & Millipore \\
\hline Anti-synapsin 1 & Whole IgG, unconjugated & Bovine synapsin I & Rabbit & $1: 200$ & Millipore \\
\hline Anti-fodrin & $\lg \mathrm{G} 1$, unconjugated & Chicken red blood-cell membranes & Mouse & $1: 4000$ & BioMol \\
\hline Anti-STEP & IgG1, unconjugated & Rat synthetic peptide & Mouse & $1: 1000$ & Boulanger et al., 1995 \\
\hline Anti-Bax & Whole IgG, unconjugated & Human synthetic peptide & Rabbit & $1: 1000$ & Sigma-Aldrich \\
\hline Anti-tubulin & $\lg \mathrm{G} 1$, unconjugated & Purified chick brain tubulin & Mouse & $1: 500$ & Sigma-Aldrich \\
\hline Anti-NCX-3 & Whole IgG, unconjugated & Extracellular domain of human NCX-3 & Goat & $1: 1000$ & Santa Cruz Biotechnology \\
\hline Anti-rabbit & Whole IgG peroxidase-conjugated & Rabbit Fc & Donkey & $1: 10,000$ & GE Healthcare \\
\hline Anti-mouse & Whole IgG peroxidase-conjugated & Mouse Fc & Sheep & $1: 10,000$ & GE Healthcare \\
\hline Anti-goat & Whole IgG peroxidase-conjugated & Goat Fc & Donkey & $1: 10,000$ & Santa Cruz Biotechnology \\
\hline Anti-rabbit & Whole IgG Alexa Fluor 594-conjugated & Rabbit Fc & Goat & $1: 600$ & Invitrogen \\
\hline Anti-mouse & Whole IgG Alexa Fluor 488-conjugated & Mouse Fc & Goat & $1: 600$ & Invitrogen \\
\hline
\end{tabular}

ternalization of the NR1/NR2B receptor complex (Snyder et al., 2005). STEP activity also mediates internalization of GluR1/ GluR2-containing AMPA receptors (AMPARs) after activation of group I metabotropic glutamate receptors, although whether this is attributable to a direct dephosphorylation of GluR2 remains to be determined (Zhang et al., 2008).

STEP $_{61}$ is a substrate for the $\mathrm{Ca}^{2+}$-dependent protease calpain and is rapidly cleaved to a smaller isoform $\left(\mathrm{STEP}_{33}\right)$ after strong glutamatergic stimulation, such as during excitotoxic or ischemic insult (Nguyen et al., 1999; Gurd et al., 1999; Braithwaite et al., 2008). Although calpain-dependent conversion of $\mathrm{STEP}_{61}$ to $\mathrm{STEP}_{33}$ has been known to occur, the functional significance of this has not been assessed. Given the importance of STEP $_{61}$ in regulating neurotransmission and its susceptibility to excitotoxicity, we evaluated the differential effects of activation of synaptic versus extrasynaptic NMDARs with regard to possible calpainmediated inactivation of STEP $_{61}$ and subsequent activation of p38 and cell death pathways. These results implicate the proteolysis of STEP $_{61}$ as a potential target for neuroprotection from glutamatergic excitotoxicity.

\section{Materials and Methods}

Antibodies and reagents. All antibodies used in this study are listed in Table 1. Glutamate, MK-801 [(+)-5-methyl-10,11-dihydro-5H-dibenzo [a,d]cyclohepten-5,10-imine maleate], ifenprodil, CNQX, NMDA, glycine, D-AP-5, and bicuculline were purchased from Sigma-Aldrich. Calpeptin, ALLN (N-acetyl-Leu-Leu-Nle-CHO), cpm-VAD-CHO, lactacystin, epoximicin, chloroquine, TTX, nifedipine, carbobenzoxy-L-leucyl-Lleucyl-L-leucinal (MG-132) and Suc-LLVY-AMC were from Calbiochem. Cdk5 small interfering RNA (siRNA) was purchased from Santa Cruz Biotechnology (Table 1).

Recombinant glutathione $S$-transferase (GST)-STEP ${ }_{46}$, GST-STEP $_{33}$, GST-STEP $_{46}$ (C to S), GST-STEP ${ }_{33}$ (C to S), and GST were affinity purified as described previously (Nguyen et al., 2002). Trans-activating transduction (TAT) $-\mathrm{STEP}_{46}$ and TAT-STEP 33 were purified from Top10 Escherichia coli by using TALON metal beads (Clontech). For inhibition of calpain-mediated cleavage of $\mathrm{STEP}_{61}$, TAT-myc peptide and TAT-STEP peptide were synthesized by the Keck Facility at Yale University (New Haven, CT).

Primary neuronal cultures and treatments. The Yale University Institu- tional Animal Care and Use Committee approved all procedures. Primary cortical neurons were isolated from rat embryonic day 18 embryos as described previously (Hu et al., 2007; Zhang et al., 2008). Cells were dissociated with trypsin and resuspended in HBSS (in mM): $137.9 \mathrm{NaCl}$, $5.3 \mathrm{KCl}, 0.33 \mathrm{Na}_{2} \mathrm{HPO}_{4}, 0.44 \mathrm{KH}_{2} \mathrm{PO}_{4}, 4.17 \mathrm{NaHCO}_{3}$, and 5.55 glucose. Cells were plated on poly-D-lysine-coated plates $\left(1 \times 10^{6}\right.$ cells per well $)$ in Neurobasal supplemented with 2\% B27 (Invitrogen) and grown for 14-21 d. To stimulate neurons with glutamate, cells were washed with HBSS buffer, and the initial medium was replaced by medium containing $100 \mu \mathrm{M}$ glutamate for the indicated periods of time. In some experiments, inhibitors and antagonists were added to the medium $30 \mathrm{~min}$ before and throughout the treatment with glutamate $(100 \mu \mathrm{M})$ for $60 \mathrm{~min}$.

Stimulation of synaptic versus extrasynaptic NMDAR. Synaptic versus extrasynaptic stimulations were performed as described in previously established protocols (Hardingham et al., 2002; Ivanov et al., 2006; Léveillé et al., 2008). Briefly, cortical neurons were plated $\left(7 \times 10^{4}\right.$ cells/ $\mathrm{cm}^{2}$ ) in minimum essential medium (MEM) with $10 \% \mathrm{Nu}$ serum (BD Biosciences). At days 3, 7, and 13, half of the medium was changed to MEM and 2\% B27. Neurons were preincubated in medium containing TTX (1 $\mu \mathrm{M})$, CNQX (40 $\mu \mathrm{M})$, D-AP-5 (100 $\mu \mathrm{M})$, and nifedipine (5 $\mu \mathrm{M})$ for $3 \mathrm{~h}$ before stimulation.

For synaptic stimulation, cells were incubated in medium containing bicuculline $(10 \mu \mathrm{M})$, glycine $(10 \mu \mathrm{M})$, and nifedipine $(5 \mu \mathrm{M})$ for $15 \mathrm{~min}$.

For extrasynaptic stimulation, synaptic NMDARs were irreversibly blocked by the addition of MK-801 $(50 \mu \mathrm{M})$ for $5 \mathrm{~min}$ under the conditions stated above (10 $\mu \mathrm{M}$ bicuculline, $10 \mu \mathrm{M}$ glycine, and $5 \mu \mathrm{M}$ nifedipine). Subsequently, the medium was changed to include TTX (1 $\mu \mathrm{M})$, CNQX (40 $\mu \mathrm{M})$, nifedipine (5 $\mu \mathrm{M}), \operatorname{NMDA}(10 \mu \mathrm{M})$, and glycine $(10 \mu \mathrm{M})$ for $15 \mathrm{~min}$.

For stimulation of all NMDARs, neurons were incubated in medium containing TTX (1 $\mu \mathrm{M})$, CNQX (40 $\mu \mathrm{M})$, nifedipine (5 $\mu \mathrm{M})$, NMDA (10 $\mu \mathrm{M})$, and glycine $(10 \mu \mathrm{M})$ for $15 \mathrm{~min}$. Immediately after stimulation, neurons were rapidly lysed in radioimmunoprecipitation assay (RIPA) buffer as described previously (Braithwaite et al., 2008).

Calpain activity assay. Cortical neurons treated with synaptic and extrasynaptic stimulations as described above were used for the calpain activity assay. The same amount of neuron lysates were diluted in assay buffer (50 mm Tris- $\mathrm{HCl}, \mathrm{pH} 7.4,10 \mathrm{~mm} \mathrm{CaCl}_{2}$, and $2 \mathrm{~mm} \mathrm{DTT}$ ) in the presence of a fluorogenic calpain substrate Suc-LLVY-AMC (Calbiochem). Cleavage of Suc-LLVY-AMC by calpain to its fluorescent product aminomethylcoumarin (AMC) was used to measure calpain activity as described previously (Meng et al., 1999; Boland and Campbell, 2003). 
After $30 \mathrm{~min}$ incubation at room temperature, reactions were stopped by the addition of an equal volume of $125 \mathrm{~mm}$ sodium borate buffer, $\mathrm{pH}$ 9.0, containing $7.5 \%$ ethanol. Fluorescence was assessed measuring excitation at $360 \mathrm{~nm}$ and emission at $440 \mathrm{~nm}$ using a fluorescence plate reader.

siRNA transfection. Cdk5 siRNA (Santa Cruz Biotechnology) is a pool of three target-specific 20-25 nt siRNAs designed to knockdown Cdk5 expression. Final concentrations ( $80 \mathrm{~nm}$ ) of siRNAs were transfected into primary cortical neurons at $6 \mathrm{~d}$ in vitro (DIV) using Lipofectamine 2000 reagent according to the instructions of the manufacturer. After 6-8 d of growth in the presence of the siRNAs, neurons were stimulated with synaptic or extrasynaptic protocols and harvested in RIPA buffer.

Slice preparations and treatments. Adult male Sprague Dawley rats (6-8 weeks; Charles River Laboratories) or male STEP wild-type (WT) and knock-out $(\mathrm{KO})$ mice $(8-10$ weeks) were used for all biochemical experiments. Brains were removed and placed in ice-cold oxygenated artificial CSF (aCSF) (in mM): $124 \mathrm{NaCl}, 4 \mathrm{KCl}, 26 \mathrm{NaHCO}_{3}, 1.5 \mathrm{CaCl}_{2}$, $1.25 \mathrm{KH}_{2} \mathrm{PO}_{4}, 1.5 \mathrm{MgSO}_{4}$, and $10 \mathrm{D}$-glucose. Coronal corticostriatal slices $(300 \mu \mathrm{m})$ were equilibrated for $60 \mathrm{~min}$ in aCSF at $30^{\circ} \mathrm{C}$ under constant oxygenation with $95 \% \quad \mathrm{O}_{2} / 5 \% \mathrm{CO}_{2}$. Slices were transduced with TAT-STEP $_{46}$, TAT $\mathrm{STEP}_{33}$, or TAT-myc $(2 \mu \mathrm{M})$ for $30 \mathrm{~min}$ before homogenization and subcellular fractionation. This treatment allows transduction of nearly $100 \%$ of cells (Paul et al., 2007). In some experiments, corticostriatal slices from STEP WT and KO mice were allowed to recover for $60 \mathrm{~min}$ before oxygen-glucose deprivation (OGD).

Hippocampal slice recordings. For electrophysiology experiments, slices were prepared and whole-cell recordings obtained as described previously by Proctor et al. (2006). The TAT-STEP peptide or TAT-myc was added to the internal recording electrode solution at $100 \mathrm{~nm}$. To calculate the ratio of NMDA EPSCs and GABA IPSCs, the neuron was voltage clamped at $-55 \mathrm{mV}$, and NMDA EPSCs were measured first by increasing the stimulus strength to determine the maximal stimulus input. The stimulus strength was then adjusted to $70-80 \%$ of the maximum. The steady-state amplitude of NMDA EPSCs was measured under this stimulus parameter. Subsequently, the $\mathrm{GABA}_{\mathrm{A}}$ receptor antagonist (bicuculline) was washed out to reveal the GABA IPSC steady-state amplitude under this identical stimulus parameter.

Subcellular fractionation. Slices were homogenized in TEVP buffer (in mM): 10 Tris, pH 7.4, $5 \mathrm{NaF}, 1 \mathrm{Na}_{3} \mathrm{VO}_{4}, 1$ EDTA, 1 EGTA, and protease inhibitor cocktail (Roche) and processed as described previously (Hu et al., 2007). In brief, homogenates were centrifuged at $1000 \times g$ for $10 \mathrm{~min}$ to form S1 and P1 fractions. The S1 fraction was further centrifuged at $10,000 \times g$ for $15 \mathrm{~min}$ to obtain a crude synaptosomal fraction (P2) and supernatant (S2). P2 fractions were subsequently resuspended and lysed in hypo-osmotic TEVP buffer containing $35.6 \mathrm{~mm}$ sucrose and centrifuged at $25,000 \times g$ for 20 min to yield the synaptosomal membrane fractions (LP1).

To evaluate the localization of $\mathrm{p} 38$ and ERK1/2 in synaptic and extrasynaptic membranes, we performed detergent extraction on P2 fractions using $0.5 \%$ Triton X-100 as described previously (Gardoni et al., 2006; Davies et al., 2007; Goebel-Goody et al., 2009) to enrich membranes for synaptic and extrasynaptic proteins.

Synaptosomes were prepared from WT and Cdk5 conditional KO (cKO) mice as described previously (Hawasli et al., 2007). In brief, hippocampi and cortex/striatum from adult animals were dissected and homogenized. Synaptosomal preparations were purified via multiple centrifugation steps and sucrose gradients. Sample containing synaptosomal preparation was subjected to SDS-PAGE and immunoblot analysis. Data represent pooled samples from three cKO and WT animals.

Protein extraction of the crude mitochondrial fraction was performed as described previously (Fujimura et al., 1998) with modification. In brief, corticostriatal slices were homogenized in lysis buffer (in mM): 20 HEPES, pH 7.5, 250 sucrose, $10 \mathrm{KCl}, 1.5 \mathrm{MgCl}_{2}, 5 \mathrm{NaF}, 1 \mathrm{Na}_{3} \mathrm{VO}_{4}, 1$ EDTA, 1 EGTA, 1 dithiothreitol, and protease inhibitor cocktail. The homogenates were centrifuged at $800 \times g$ for $10 \mathrm{~min}$ at $4^{\circ} \mathrm{C}$, and the supernatant was centrifuged at $8000 \times g$ for $20 \mathrm{~min}$. The pellet was solubilized in SDS sample buffer and used as the crude mitochondrial fraction. The supernatant was centrifuged at $100,000 \times g$ for $60 \mathrm{~min}$ to obtain the cytosolic fraction.

Oxygen and glucose deprivation. OGD was performed as described pre- viously (Zhou and Baudry, 2006). In brief, corticostriatal slices in control groups were washed and incubated with $2 \mathrm{ml}$ of aCSF solution saturated with $95 \% \mathrm{O}_{2} / 5 \% \mathrm{CO}_{2}$. Slices in the OGD groups were washed with OGD solution [in mm: $124 \mathrm{NaCl}, 4 \mathrm{KCl}, 26 \mathrm{NaHCO}_{3}, 1.5 \mathrm{CaCl}_{2}, 1.25 \mathrm{KH}_{2} \mathrm{PO}_{4}$, and $1.5 \mathrm{MgSO}_{4}$ (saturated with $95 \% \mathrm{~N}_{2} / 5 \% \mathrm{CO}_{2}$ )] and then transferred into $2 \mathrm{ml}$ of fresh OGD solution and incubated for $2 \mathrm{~h}$. TAT-STEP peptide $(1$ or $4 \mu \mathrm{M})$, TAT-myc $(4 \mu \mathrm{M})$, or calpeptin $(10 \mu \mathrm{M})$ was applied 30 min before OGD stimulation and remained in the solution throughout the experiment. At the end of the OGD period, slices were further incubated for $2 \mathrm{~h}$ in $2 \mathrm{ml}$ of fresh aCSF solution saturated with $95 \%$ $\mathrm{O}_{2} / 5 \% \mathrm{CO}_{2}$. After various treatments, medium was collected for lactate dehydrogenase $(\mathrm{LDH})$ measurements or tissues were quickly frozen in dry ice.

Assessment of neuronal viability. We used three independent techniques to assess and quantify cell death. We first measured LDH release using a CytoTox assay kit (Promega) following the protocol of the manufacturer. Second, we assessed cell viability by using MAP2 staining as described previously (Carrier et al., 2006). In brief, cortical neurons were rinsed three times with $0.1 \mathrm{M}$ PBS, pH 7.4, and fixed with $4 \%$ paraformaldehyde in PBS. Fixed cultures were blocked with $10 \%$ normal goat serum (NGS) and $1 \%$ BSA in PBST $(0.2 \%$ Triton X-100) for $1 \mathrm{~h}$ at room temperature. Cultures were incubated overnight with anti-MAP2 antibody in $1 \%$ BSA in PBST $(0.2 \%$ Triton $\mathrm{X}-100)$ at $4^{\circ} \mathrm{C}$ and after washes with HRP-conjugated donkey anti rabbit secondary antibody $1 \mathrm{~h}$ at room temperature. MAP2 immunoreactivity was measured by adding $50 \mu \mathrm{M}$ Amplex Red (Invitrogen) in $300 \mu$ lof reaction buffer (50 mm sodium phosphate buffer, $\mathrm{pH} 7.4$, and $200 \mu \mathrm{M}$ hydrogen peroxide). After $30 \mathrm{~min}$ of incubation, $100 \mu \mathrm{l}$ of was transferred to a 96-well plate, and the resorufin absorbance was measured at $565 \mathrm{~nm}$. Third, we assessed cell death during glutamate stimulation in the absence or presence of TAT-STEP peptide by looking at alterations in nuclear morphology using the nucleic acid stain 4',6'-diamidino-2-phenylindole (DAPI) (Vector Laboratories). Healthy cells display diffuse staining of the nucleus, whereas injured or dead cells show nuclear morphological changes, such as chromatin condensation, nuclear condensation, and fragmentation (Cummings and Schnellmann, 2004). At least 250 randomly selected cells were counted for each stimulation condition.

Calpain cleavage of STEP in vitro and protein sequencing. Recombinant GST-STEP $_{46}$ fusion protein $(100 \mathrm{ng})$ was digested with constitutively active calpain 1 (Calbiochem) at the indicated concentrations in diges-

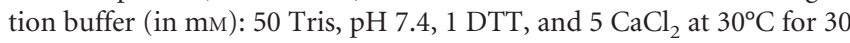
min. STEP ${ }_{46}$, contained in its entirety in $\mathrm{STEP}_{61}$, was used to circumvent technical difficulty in expression and purification of full-length forms of membrane-associated $\mathrm{STEP}_{61}$. After digestion, samples were subjected to SDS-PAGE and transferred to polyvinylidene difluoride membrane (Millipore Corporation), and the band corresponding to $\mathrm{STEP}_{33}$ was excised and sent to Yale Keck Facility for protein sequencing. In some experiments, TAT-STEP peptide (at specified concentrations) or Cdk5/ p25 (50 ng/ $\mu \mathrm{l})$ was added to the reaction.

Precipitation with GST fusion proteins. GST, GST-STEP ${ }_{46}$ (C to S), or $\mathrm{GST}-\mathrm{STEP}_{33}(\mathrm{C}$ to $\mathrm{S})(10 \mu \mathrm{g})$ was bound to glutathione Sepharose beads (GE Healthcare) for $1 \mathrm{~h}$ at $4^{\circ} \mathrm{C}$. This catalytic domain mutation (C to S) renders STEP inactive, without affecting its ability to bind to its substrates via the kinase interacting motif (KIM). These mutant STEP isoforms are used as substrate-trapping mutants (Snyder et al., 2005; Paul et al., 2007; Tashev et al., 2009). Washed beads were incubated with rat brain homogenates $(100 \mu \mathrm{g})$ in RIPA buffer for $2 \mathrm{~h}$, washed, and subjected to SDS-PAGE, followed by immunoblotting.

STEP phosphatase activity. Phospho-p38 dephosphorylation by GST$\mathrm{STEP}_{46}$ or GST-STEP 33 was conducted by incubating increasing amounts of GST-STEP ${ }_{46}$ or $\mathrm{STEP}_{33}$ proteins with $10 \mathrm{ng}$ of phospho-p38 (Millipore Corporation) in phosphatase assay buffer (in mM: 25 HEPES, $\mathrm{pH} 7.3,5 \mathrm{EDTA}$, and $10 \mathrm{DTT}$ ) at $30^{\circ} \mathrm{C}$ for $30 \mathrm{~min}$. The reactions were terminated by adding SDS sample buffer, and samples were subjected to SDS-PAGE (10\%). The C terminus of the NMDA receptor subunit NR2B, fused to GST (GST-NR2Bc), was purified, and $1 \mu \mathrm{g}$ was phosphorylated by Fyn kinase ( $50 \mathrm{ng}$; Millipore Corporation) in kinase buffer (in mM): 50 Tris- $\mathrm{HCl}, \mathrm{pH} 7.4,0.1 \mathrm{EGTA}, 10 \mathrm{MgCl}_{2}$ and $500 \mu \mathrm{M}$ ATP. Phosphorylated GST-NR2Bc was incubated with GST-STEP ${ }_{46}$ or GST- 
A
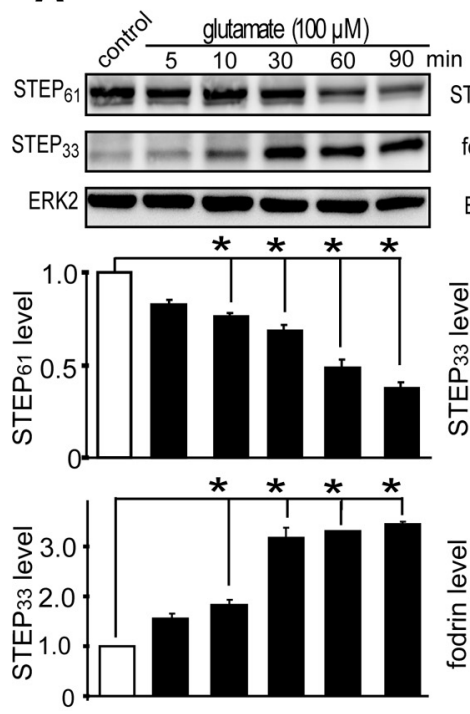

B
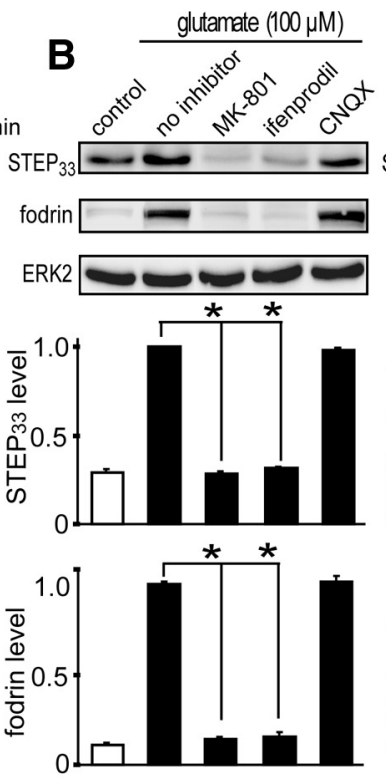
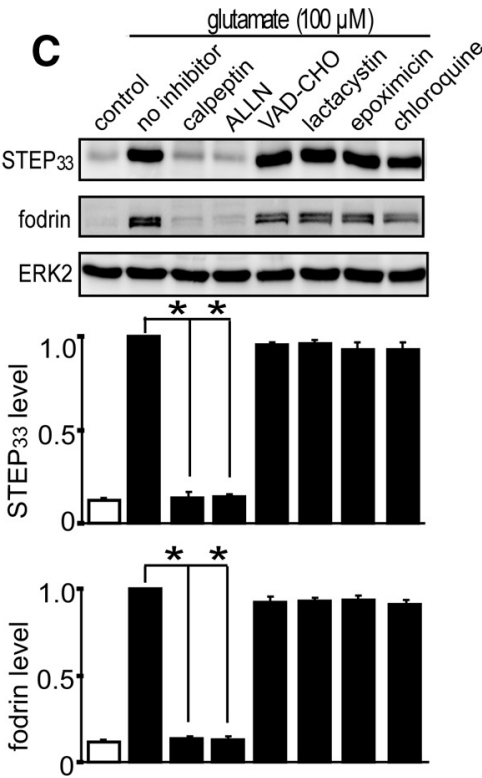

Figure 1. NMDAR-dependent cleavage of STEP 61 by calpain. $\boldsymbol{A}_{\text {, Immunoblots of } \text { STEP }_{61} \text { and STEP }}$ from primary cortical neurons lysates treated with glutamate for the indicated periods. Representative immunoblots (top) and quantitation (bottom) are shown for each ( ${ }^{*} p<0.01$ compared with control, one-way ANOVA with post hoc Tukey's test; $n=3$ ). ERK2 was used to normalize the data. $\boldsymbol{B}$, Immunoblots of STEP 33 and fodrin from cortical neurons treated with glutamate in the presence of MK-801 (50 $\mu \mathrm{M})$, ifenprodil (10 $\mu \mathrm{M})$, or CNQX (40 $\mu \mathrm{M})$. Activation of calpain was confirmed by fodrin proteolysis. Histogram shows the quantitative analysis of STEP ${ }_{33}$ production and fodrin cleavage normalized to ERK2 ( $p<0.01$, Student's $t$ test; $n=3$ ). $C$, Immunoblot analyses are shown of lysates from cortical neurons treated with glutamate in the presence of the calpain inhibitors calpeptin (10 $\mu \mathrm{m})$ or ALLN (20 $\mu \mathrm{m})$, the caspase inhibitor cpm-VAD-CH0 (20 $\mu \mathrm{m})$, the proteasome inhibitors lactacystin $(5 \mu \mathrm{m})$ or epoximicin $(5 \mu \mathrm{m})$, or the lyzosome inhibitor chloroquine $(500 \mu \mathrm{m})\left({ }^{*} p<0.01\right.$, Student's $t$ test; $\left.n=3\right)$.

STEP $_{33}$ in phosphatase assay buffer at $30^{\circ} \mathrm{C}$ for $30 \mathrm{~min}$. To determine the phosphorylation state of $\mathrm{pY}^{1472} \mathrm{NR} 2 \mathrm{~B}$, samples were resolved by SDSPAGE, transferred to nitrocellulose membrane, and immunoblotted with anti-pY ${ }^{1472}$ NR2B antibody. Densitometric quantification was performed using the Genetools program (Syngene).

Immunofluorescence and immunoblotting. Cortical neurons were grown in Neurobasal medium with 2\% B27. Cultures (DIV 12-14) were

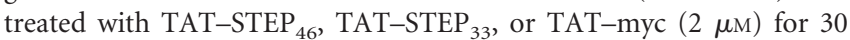
$\mathrm{min}$, then rinsed with $0.1 \mathrm{M}$ PBS, and fixed in $4 \%$ paraformaldehyde with $4 \%$ sucrose. Cells were permeabilized with PBS with $0.2 \%$ Triton X-100 and blocked with $10 \%$ NGS and 1\% BSA for $1 \mathrm{~h}$. Cultures were stained with anti-NR1 and anti-synapsin I antibodies overnight at $4^{\circ} \mathrm{C}$ and incubated with goat anti-rabbit Alexa Fluor 594 or goat anti-mouse Alexa Flour 488 secondary antibodies (1:600; Invitrogen). Microscopy was performed with a Carl Zeiss Axiovert 2000 microscope with an apotome (Applied Scientific Instruments) using a $100 \times$ objective lens. All analyses were performed blind to the stimulation conditions of the culture. NR1 puncta were counted along the proximal $10 \mu \mathrm{m}$ of three or more dendrites per neuron, and 20 neurons were used for quantification per treatment. The data were analyzed with a one-way ANOVA with post hoc Tukey's test.

Immunoblotting was conducted as described previously ( $\mathrm{Hu}$ et al., 2007; Zhang et al., 2008). Membranes were washed and incubated in peroxidase-conjugated secondary antibodies (1:5000-1:10,000; GE Healthcare). Bands were visualized using a Chemiluminescent Substrate kit (Pierce) and captured by a G:BOX with the image program GeneSnap (Syngene). All densitometric quantifications were performed using the Genetools program (Syngene).

Statistical analysis. All experiments were repeated at least three times. Data were expressed as means \pm SEM. Statistical significance $(p<0.05)$ was determined by Student's $t$ test. For some experiments, data were analyzed with one-way ANOVA with post hoc Tukey's test or post hoc least significant difference test.

\section{Results}

Calpain-cleavage of STEP $_{61}$ is NMDAR dependent

$\mathrm{STEP}_{61}$ is cleaved to a smaller isoform $\left(\mathrm{STEP}_{33}\right)$ after glutamate stimulation of cortical cultures or an ischemic insult to the cortex
(Gurd et al., 1999; Nguyen et al., 1999; Braithwaite et al., 2008). We were interested in determining the functional significance of STEP $_{61}$ proteolysis. In an initial experiment, primary cortical neurons (DIV 14) were stimulated with glutamate $(100 \mu \mathrm{M})$ at different time points (Fig. 1A). As was observed previously, $\mathrm{STEP}_{33}$ was produced in response to glutamate in a timedependent manner with marked levels occurring by $30 \mathrm{~min}$ $(317.4 \pm 20.6 \%$ of control at $30 \mathrm{~min} ; p<0.01)$, with a concomitant decrease in $\operatorname{STEP}_{61}(68.6 \pm 3.0 \%$ of control at 30 $\min ; p<0.01)$.

We next determined whether the cleavage of STEP $_{61}$ was NMDAR dependent (Fig. $1 B$ ). Treatment of cortical cultures with the NMDAR antagonist MK-801 30 min before glutamate significantly decreased the production of $\mathrm{STEP}_{33}(28.4 \pm 1.2 \%$ compared with no inhibitor control, $p<0.01$ ). Furthermore, the NR2B-specific antagonist ifenprodil similarly attenuated STEP 33 generation in response to glutamate stimulation $(31.4 \pm 0.8 \%$; $p<0.01$ ). In contrast, the AMPAR antagonist CNQX failed to block STEP $_{61}$ cleavage $(98.2 \pm 1.3 \%$ of no inhibitor control; $p>$ $0.05)$. For this analysis, we also compared the generation of $\mathrm{STEP}_{33}$ to the production of fodrin, a known substrate of calpain (Siman et al., 1984). Fodrin cleavage was also blocked by MK-801 and ifenprodil $(14.0 \pm 1.7$ and $15.6 \pm 2.4 \%$, respectively, of no inhibitor control; $p<0.01)$. These results suggested that the cleavage of $\mathrm{STEP}_{61}$ required activation of NR2B-containing NMDARs.

To confirm that conversion of $\mathrm{STEP}_{61}$ to $\mathrm{STEP}_{33}$ was mediated by activated calpain, we assessed the effects of a panel of proteolytic inhibitors (Fig. 1C). Two different calpain inhibitors, calpeptin and ALLN, blocked the cleavage of STEP $_{61}(13.7 \pm 3.0$ and $14.4 \pm 1.0 \%$ of no inhibitor control; $p<0.01$ ). However, the pan-caspase inhibitor cpm-VAD-CHO, the proteasome inhibitors lactacystin and epoximicin, and the lyzosome inhibitor chloroquine did not prevent cleavage $(95.4 \pm 1.6,96.3 \pm 2.1$, 
$92.9 \pm 4.0$, and $93.3 \pm 3.7 \%$, respectively, of no inhibitor control; $p>0.05$ ). These results suggested that the cleavage of STEP $_{61}$ was mediated by calpain.

\section{Activation of extrasynaptic NMDARs leads to STEP cleavage and neuronal cell death}

The above experiments were conducted by adding glutamate directly to the medium, thereby activating both synaptic and extrasynaptic NMDARs. However, substantial evidence suggests that these two populations of ionotropic glutamate receptors have dramatically different effects on neuronal activity. In addition, a recent study has shown that STEP $_{61}$ is present at both synaptic and extrasynaptic sites (Goebel-Goody et al., 2009). Therefore, we used a pharmacological protocol to stimulate synaptic or extrasynaptic receptors (Hardingham et al., 2002; Ivanov et al., 2006) to determine which subgroup contributes to STEP $_{61}$ cleavage. To validate the stimulation conditions, we first confirmed that synaptic, but not extrasynaptic, stimulation led to phosphorylation of ERK at $\mathrm{Thr}^{202} / \mathrm{Tyr}^{204}$ (synaptic, $329.6 \pm$ $46.5 \%$ of control, $p<0.01$; extrasynaptic, $96.1 \pm 2.0 \%$ of control, $p>0.05$ ) (Fig. 2A) (Ivanov et al., 2006). In contrast, extrasynaptic stimulation, but not synaptic stimulation, led to the phosphorylation of p38 at $\mathrm{Thr}^{180} / \mathrm{Tyr}^{182}$ under our stimulation conditions (extrasynaptic, $186.6 \pm 10.3 \%, p<0.01$ synaptic, $118.1 \pm 9.0 \%$ of control, $p>0.05)$ (Fig. $2 A)$.

ERK $1 / 2$ and 38 may be preferentially activated after synaptic or extrasynaptic NMDAR stimulation, respectively, because they are differentially expressed in synaptic and extrasynaptic membranes. To address this question, we prepared synaptic and extrasynaptic membranes from cortical tissue using previously established protocols (Gardoni et al., 2006; Davies et al., 2007; GoebelGoody et al., 2009). We found that the concentration of p38 was significantly greater in extrasynaptic membranes than in synaptic membranes $(p<0.05)$. Although ERK1/2 was expressed in both membrane compartments, it did not significantly differ between synaptic and extrasynaptic membranes (supplemental Fig. 1, available at www.jneurosci.org as supplemental material). Given that p38 was most enriched extrasynaptically, these findings could provide an explanation for why extrasynaptic stimulation preferentially activates $\mathrm{p} 38$.

Transient activation of $\mathrm{p} 38$ after synaptic stimulation has been reported (Waxman and Lynch, 2005). Here we confirmed transient activation of p 38 after synaptic stimulation, which gradually decreased to basal levels by $15 \mathrm{~min}$. However, we found no significant cleavage of $\mathrm{STEP}_{61}$ under these conditions (supplemental Fig. $2 A, B$, available at www.jneurosci.org as supplemental material). In contrast, extrasynaptic stimulation led to a progressive and significant increase in p-p38 levels that was accompanied by cleavage of $\mathrm{STEP}_{61}$ to $\mathrm{STEP}_{33}$ (supplemental Fig. 2C, D, available at www. jneurosci.org as supplemental material). These findings demon-
B
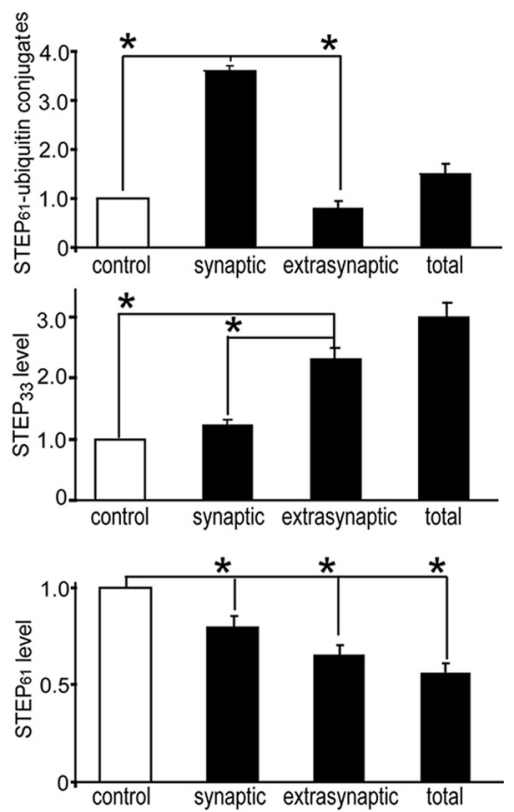

Figure 2. Activation of extrasynaptic NMDARs causes STEP ${ }_{61}$ cleavage and neuronal death. $\boldsymbol{A}$, Immunoblot analysis comparing hoc Tukey's test; $n=4)$. $C$, Analysis of excitotoxic cell death of cortical neurons subjected to synaptic or extrasynaptic stimulations. Cytotoxicity was assessed by measurement of $L D H$ release ( ${ }^{*} p<0.01$, Student's $t$ test; $n=3$ ).

strate that extrasynaptic NMDAR stimulation leads to activation of calpain, cleavage of STEP $_{61}$, and phosphorylation of $\mathrm{p} 38$.

$\mathrm{STEP}_{61}$ regulates the activation state of both $\mathrm{p} 38$ and ERK1/2 by dephosphorylating them. We hypothesized that differential inactivation of STEP $_{61}$ by synaptic or extrasynaptic NMDARs impairs the ability of STEP to dephosphorylate and inactivate these substrates and could therefore underlie the selective activation of ERK1/2 or p38 pathways. To address this question, we evaluated how synaptic and extrasynaptic stimulation of NMDARs regulates $\mathrm{STEP}_{61}$ degradation. We found that synaptic NMDAR stimulation caused a significant increase in the ubiquitination of $\mathrm{STEP}_{61}$ (Fig. $2 \mathrm{~B}$, top) (358.0 $\pm 10.3 \%$ of control; $p<0.01)$, whereas extrasynaptic NMDAR stimulation did not alter ubiquitinated STEP $_{61}$ levels $(83.0 \pm 15.6 \%$ of control; $p>$ $0.05)$. These results suggest that ubiquitination of STEP $_{61}$ occurs as a result of synaptic NMDAR stimulation but not extrasynaptic stimulation.

In contrast, extrasynaptic stimulation led to $\mathrm{STEP}_{61}$ proteolysis and a concomitant production of $\operatorname{STEP}_{33}(230.3 \pm 19.1 \%$ of control; $p<0.01)$, whereas synaptic stimulation did not $(118.6 \pm$ $9.3 \% ; p>0.05$ ) (Fig. 2 B, middle). When glutamate was added to the cortical cultures (stimulation of both synaptic and extrasynaptic receptors), both $\mathrm{STEP}_{61}$ and fodrin were cleaved (Fig. 1) (supplemental Fig. $2 E$, available at www.jneurosci.org as supplemental material). There was a concomitant decrease in STEP $_{61}$ levels after both synaptic and extrasynaptic stimulations (Fig. 2 B, 
A
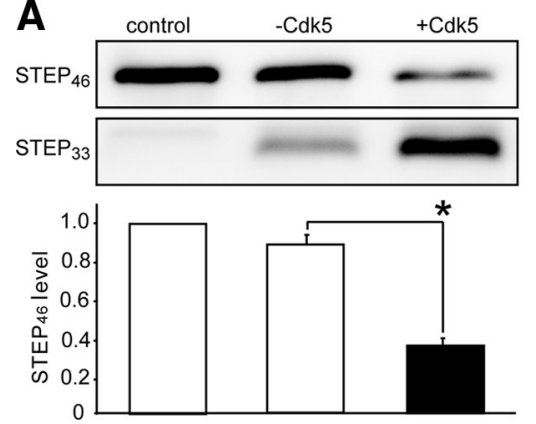

*
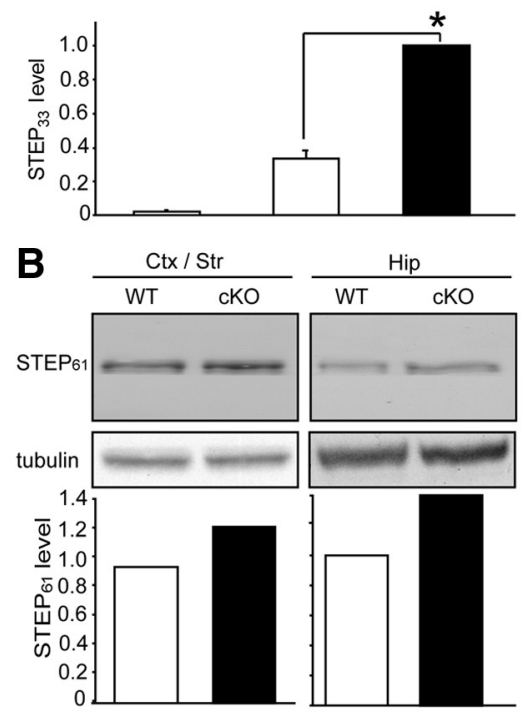

C

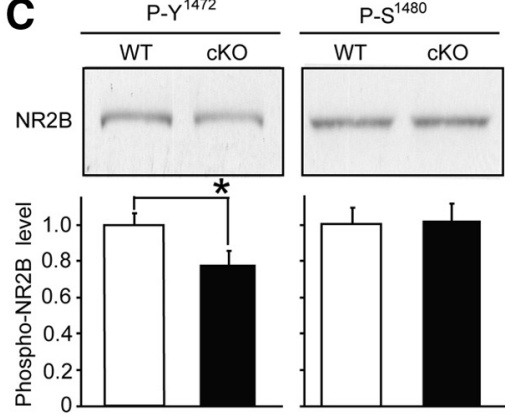

D
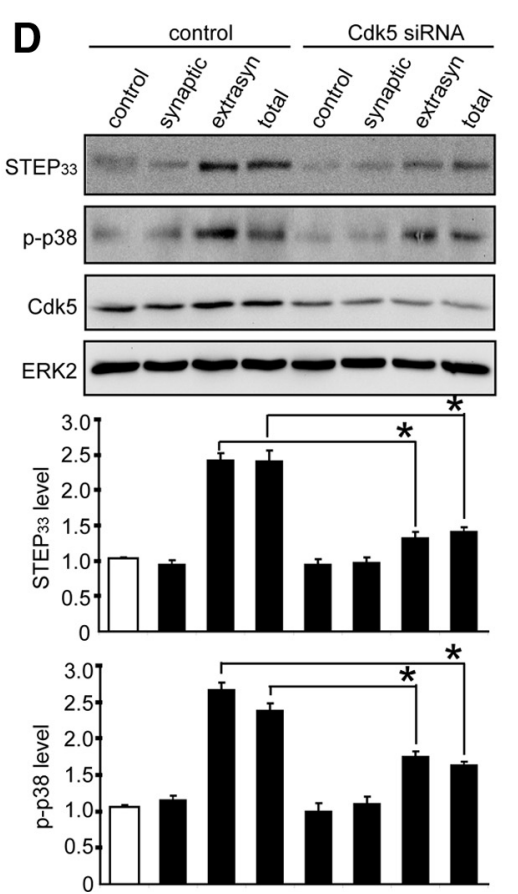

Figure 3. Regulation of STEP cleavage by Cdk5. A, GST-STEP ${ }_{46}$ was digested with calpain 1 in the absence or presence of recombinant $C \mathrm{dk} 5 / \mathrm{p} 25$ proteins $(50 \mathrm{ng} / \mu \mathrm{l})$. Immunoreactivity of noncleaved GST-STEP ${ }_{46}$ was normalized to control without calpain ( ${ }^{*} p<0.01$, one-way ANOVA with post hoc Tukey's test; $n=3$ ). $\boldsymbol{B}$, Immunoblot analysis and quantitation of STEP $_{61}$ and tubulin loading controls in corticostriatal and hippocampal synaptosomes. Tissues from three animals per genotype were pooled. Ctx, Cortex; Str, striatum; Hip, hippocampus. C, Levels of indicated phosphorylation sites in hippocampal lysates from Cdk5 CK0 and WT mice. Phosphorylation sites are normalized to total protein levels ( ${ }^{*} p<0.05$, Student's $t$ test; $n=6$ ). D, STEP cleavage and $p 38$ activation in Cdk5 siRNA-transfected cortical neurons. Extrasynaptic stimulation and total glutamate bath-induced STEP cleavage was significantly reduced in Cdk5 siRNA-transfected neurons. Moreover, activation of p38 was significantly blocked in Cdk5 siRNA-transfected neurons during extrasynaptic stimulation as well as total glutamate bath $\left({ }^{*} p<0.01\right.$, one-way ANOVA with post hoc Tukey's test; $n=3$ ).

pain substrate Suc-LLVY-AMC as described (supplemental Methods, available at www.jneurosci.org as supplemental material). We found a significant increase of calpain activity during stimulation of extrasynaptic NMDARs compared with synaptic NMDARs $(p<0.01)$ (supplemental Fig. 2G, available at www. jneurosci.org as supplemental material).

Previous studies have found that extrasynaptic stimulation activates cell death pathways, whereas synaptic stimulation promotes cell survival (Hardingham et al., 2002; Martel et al., 2009). We therefore assessed cell cytotoxicity after synaptic or extrasynaptic stimulation by measuring release of $\mathrm{LDH}$ into the medium (Fig. 2C). Stimulation of extrasynaptic NMDARs for $15 \mathrm{~min}$ led to a significant increase of $\mathrm{LDH}$ release $(457.6 \pm 21.2 \%$ of control; $p<0.01$ ), whereas synaptic stimulation had no significant effect $(98.0 \pm 8.5 \%$ of control; $p>0.05$ ). Addition of glutamate to the cultures also led to significant release of LDH ( $492.0 \pm 25.9 \%$ of control; $p<0.01)$. These findings were confirmed by an assay of neuron viability, based on MAP2 immunoreactivity (Brooke et al., 1999; Carrier et al., 2006). Extrasynaptic stimulation decreased MAP2 immunoreactivity, indicating decreased cell viability $(65.8 \pm 6.7 \%$ of control; $p<0.01$ ), whereas activation of synaptic NMDARs did not $(94.6 \pm 7.2 \%$ of control; $p>0.05$ ). Total glutamate treatment of cultures also induced a significant decrease in MAP2 immunoreactivity $(63.1 \pm 7.2 \%$ of control; $p<$ $0.01)$. These findings suggested that extrasynaptic stimulation led both to the phosphorylation of p38 and the induction of cell death pathways and raised the possibility that these events might be related to the cleavage of $\mathrm{STEP}_{61}$. bottom) (synaptic, $79.5 \pm 5.7 \%$ of control, $p<0.01$; extrasynaptic, $65.3 \pm 4.8 \%, p<0.01)$. Together, these data indicate that synaptic stimulation selectively induces ubiquitination and degradation of $\mathrm{STEP}_{61}$, which correlated with the phosphorylation of ERK1/2. In contrast, extrasynaptic stimulation causes calpaindependent cleavage of $\mathrm{STEP}_{61}$ with concomitant phosphorylation of $\mathrm{p} 38$.

NCX-3 is a Na ${ }^{+} / \mathrm{Ca}^{2+}$ exchanger known to be cleaved by calpain under excitotoxic insults (Bano et al., 2005). Extrasynaptic stimulation, but not synaptic stimulation, led to NCX-3 proteolysis $(p<0.01)$ (supplemental Fig. $2 F$, available at www.jneurosci.org as supplemental material). In addition, extrasynaptic NMDAR stimulation significantly increased the cleavage of fodrin, another known calpain substrate $(p<0.01)$ (supplemental Fig. $2 E$, available at www.jneurosci.org as supplemental material).

We then measured calpain activity in neuronal lysates treated with synaptic or extrasynaptic stimulations using fluorogenic cal-

\section{Cdk5 enhances calpain-mediated cleavage of STEP}

A recent study demonstrated that the neuronal protein kinase Cdk5 facilitated calpain-mediated cleavage of substrates and that calpain activation was impaired in Cdk5 cKO mice (Hawasli et al., 2007). Therefore, we tested whether Cdk5 enzyme affected STEP cleavage in vitro (Fig. $3 A$ ). Recombinant GST-STEP $46(100$ $\mathrm{ng}$ ) was digested with calpain $1(0.025 \mathrm{U})$ with or without Cdk5/ p25 protein $(50 \mathrm{ng} / \mu \mathrm{l})$ under linear conditions, and STEP cleavage was assessed by immunoblotting. In the absence of Cdk5 (Fig. $3 A$ ), limited calpain cleavage of GST-STEP ${ }_{46}$ was detectable (89.4 \pm $5.0 \%$ of control for $\left.\mathrm{STEP}_{46} ; p<0.05\right)$. In contrast, the addition of Cdk5 significantly decreased $\mathrm{STEP}_{46}$ levels $(37.3 \pm 4.2$ vs $89.4 \pm$ $5.0 \% ; p<0.01)$ and significantly increased the production of $\mathrm{STEP}_{33}$ $(33.3 \pm 4.8$ vs $100 \% ; p<0.01)$. These data indicate that Cdk5 contributes to the calpain-mediated cleavage of STEP.

Given these findings and the previous indications that Cdk5 may facilitate calpain-dependent cleavage of neuronal substrates 
(Hawasli and Bibb, 2007), we examined the effects of Cdk5 loss on $\mathrm{STEP}_{61}$ levels in adult mouse brain using Cdk5 cKO mice. Immunoblot analysis showed that STEP $_{61}$ levels were elevated by 30 and $40 \%$ in synaptosomes prepared from the corticostriatum and hippocampus of $\mathrm{Cdk} 5 \mathrm{cKO}$ mice compared with WT littermate controls (Fig. $3 B$ ). Consistent with elevated STEP ${ }_{61}$ levels, the phosphorylation at $\mathrm{Tyr}^{1472}$ of NR2B was also significantly attenuated in Cdk $5 \mathrm{cKO}$ mice (Fig. $3 C$ ) (78.0 $\pm 7.0 \%$ of WT mice; $p<0.05)$, suggesting an increase in STEP activity. In contrast, pSer $^{1480}$ of NR2B was not affected $(p>0.05)$. Together, these results indicated that Cdk5 facilitated calpain-dependent cleavage of $\mathrm{STEP}_{61}$ in vivo.

To further investigate role of $\mathrm{Cdk} 5$ on $\mathrm{STEP}_{61}$ cleavage, we suppressed endogenous Cdk5 levels in cortical neurons by introducing siRNA molecules specific to $\mathrm{Cdk} 5$. After $6-8 \mathrm{~d}$ of growth in the presence of Cdk5 siRNAs, neurons were subjected to synaptic or extrasynaptic NMDAR stimulations. Cdk5 levels were significantly decreased in siRNA-transfected neurons compared with nontransfected controls $(55.1 \pm 5.3 \% ; p<0.01)$. Inhibition of Cdk5 expression with siRNA blocked calpain activity in response to extrasynaptic stimulation, leading to decreased cleavage of fodrin (data not shown). Immunoblot analysis of $\mathrm{STEP}_{33}$ showed that $\mathrm{STEP}_{61}$ cleavage is significantly attenuated in Cdk5 siRNA-transfected neurons during extrasynaptic stimulation $(135.1 \pm 10.2$ vs $244.4 \pm 13.9 \% ; p<0.01)$ (Fig. $3 D)$. In addition, we saw a concomitant decrease of p-p38 levels in Cdk5 siRNAtransfected neurons $(177.6 \pm 8.8$ vs $268.8 \pm 14.1 \% ; p<0.01)$ (Fig. 3D). These results suggest that decreased Cdk5 expression led to a decrease in calpain activation, STEP $_{61}$ cleavage, and $\mathrm{p} 38$ phosphorylation.

\section{STEP $_{33}$ does not interact with STEP substrates}

To better characterize the calpain-mediated proteolysis of STEP, in vitro cleavage reactions were conducted. Calpain cleaved recombinant STEP $_{46}$ in a dose-dependent manner $(0.01 \mathrm{U}, 70.3 \pm$ $5.7 \% ; 0.05 \mathrm{U}, 22.7 \pm 2.9 \%$; $0.1 \mathrm{U}, 3.4 \pm 2.3 \%$ of no calpain control; $p<0.01$ ) (Fig. $4 A$ ). The $\mathrm{STEP}_{33}$ band was excised and subjected to $\mathrm{N}$-terminal Edman degradation protein sequencing. This analysis revealed that STEP is predominantly cleaved by calpain between residues $\mathrm{Ser}^{224}$ and Leu ${ }^{225}$. Interestingly, this cleavage site is located within the KIM domain (Fig. 4B), which has been identified as a binding site for STEP substrates.

We therefore tested whether cleavage might disrupt the ability of STEP $_{33}$ to associate with STEP substrates. Previous studies have established that a point mutation in the catalytic domain (a cysteine to serine mutation) inactivates STEP and produces a substrate-trapping variant. GST-STEP ${ }_{46}(\mathrm{C}$ to $\mathrm{S})$ binds to its substrates but does not release them (Paul et al., 2003; Snyder et al., 2005). To determine whether calpain cleavage of STEP disrupted its ability to associate with its substrates, the $\mathrm{C}$ to $\mathrm{S}$ mutation was generated in the context of GST-STEP ${ }_{33}$ and GST-STEP ${ }_{46}$ forms of STEP. These proteins were coupled to glutathione beads and incubated with rat brain homogenates to isolate substrates of $\mathrm{STEP}_{33}$ versus $\mathrm{STEP}_{46}$. Immunoblot analysis revealed that STEP $_{33}$ lost the ability to bind to four known substrates of STEP (ERK1/2, p38, Fyn, and NR2B) compared with $\mathrm{STEP}_{46}$. As a negative control, neither $\mathrm{STEP}_{33}$ nor $\mathrm{STEP}_{46}$ bound to GluR1, which is not thought to be substrate of STEP (Fig. 5A).

As STEP $_{33}$ still contains an active phosphatase domain, it was important to establish whether it was able to dephosphorylate its substrates. To this end, we tested the ability of $\mathrm{STEP}_{33}$ to dephosphorylate p-p38 (Fig. 5B) or p-NR2B (Fig. 5C) in vitro. Purified p-p38 was incubated with active GST-STEP 46 or GST-STEP 33 ,

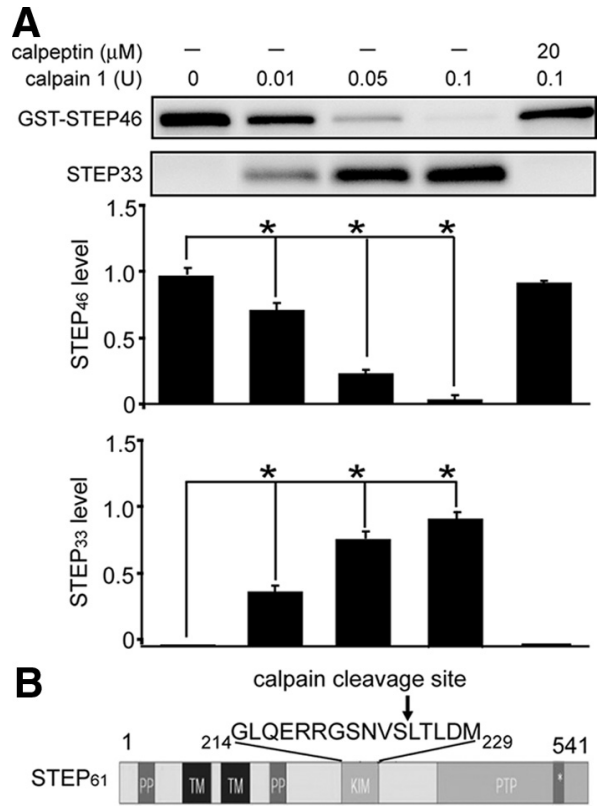

Figure 4. Identification of calpain cleavage of site. $A$, Recombinant GST-STEP ${ }_{46}$ was digested with calpain 1 at the indicated concentrations in the absence or presence of calpeptin $(20 \mu \mathrm{m})\left({ }^{*} p<\right.$ 0.01 , one-way ANOVA with post hoc Tukey's test; $n=3$ ). $\boldsymbol{B}$, After calpain digestion, the C-terminal fragment $\left(\mathrm{STEP}_{33}\right)$ was sent for amino acid sequencing. Sequence is shown surrounding the cleavage site within the KIM domain. PP, Polyproline-rich domain; TM, transmembrane; PTP, protein tyrosine phosphatase domain.

and samples were probed with p-p38 antibody. GST-STEP ${ }_{46}$ dephosphorylated p-p38 efficiently and in a concentrationdependent manner $(100 \mathrm{nM}, 16.8 \pm 3.2 \% ; 500 \mathrm{nM}, 1.5 \pm 1.2 \%$ of control; $p<0.01)$, whereas $\mathrm{STEP}_{33}$ did not $(100 \mathrm{nM}, 107.8 \pm$ $9.2 \% ; 500 \mathrm{nM}, 103.3 \pm 5.3 \%$ of control; $p>0.05)$. A similar result was derived using NR2Bc containing the regulatory $\mathrm{pY}^{1472}$ that was preparatively phosphorylated by Fyn kinase. As determined using a $\mathrm{pY}^{1472}$-specific antibody, GST-STEP 46 showed a concentration-dependent activity toward this substrate $(250 \mathrm{nM}$, $51.4 \pm 6.0 \% ; 500 \mathrm{nM}, 3.7 \pm 3.0 \%$ of control; $p<0.01$ ), whereas $\mathrm{STEP}_{33}$ was unable to dephosphorylate $\mathrm{pY}^{1472}-\mathrm{NR} 2 \mathrm{Bc}(250 \mathrm{~nm}$, $91.6 \pm 3.4 \%$; $500 \mathrm{~nm}, 93.0 \pm 2.7 \%$ of control; $p>0.05)$. These data indicated that STEP $_{33}$ was unable to bind to or dephosphorylate $\mathrm{p}$-p38 or $\mathrm{pY}^{1472}-\mathrm{NR} 2 \mathrm{Bc}$.

\section{STEP $_{33}$ prevents NMDAR endocytosis}

Given that STEP-dependent dephosphorylation of $\mathrm{pY}^{1472}$ facilitates internalization of NMDARs (NR1/NR2B), the production of STEP $_{33}$ could serve to attenuate this process. To test this hypothesis, several forms of STEP were derived bearing an 11 aa TAT peptide capable of permeabilizing cells. These forms of STEP have been confirmed to transduce into cells with near $100 \%$ efficiency (Paul et al., 2007; Zhang et al., 2008; Tashev et al., 2009). The addition of active TAT-STEP ${ }_{46}(2 \mu \mathrm{M})$ to corticostriatal slices decreased the phosphorylation level of $\mathrm{pY}^{1472}$ of NR2B and reduced the surface expression of NR2B as determined by subcellular fractionation $(66.9 \pm 4.5$ and $69.7 \pm 8.9 \%$ compared with the TAT-myc-treated control; $p<0.01$ ) (Fig. $6 A$ ). In contrast, TAT-STEP ${ }_{33}$ did not significantly dephosphorylate $\mathrm{pY}^{1472}$ and failed to reduce the surface expression of NR2B (101.7 \pm 8.4 and $105.0 \pm 9.6 \%$ of TAT-myc-treated control; $p>0.05)$. As a control, the surface expression of $\mathrm{GABA}_{\mathrm{A}}(\beta 2 / 3)$ receptors was not changed after treatment of slices with TAT-STEP ${ }_{46}$ or TAT- 

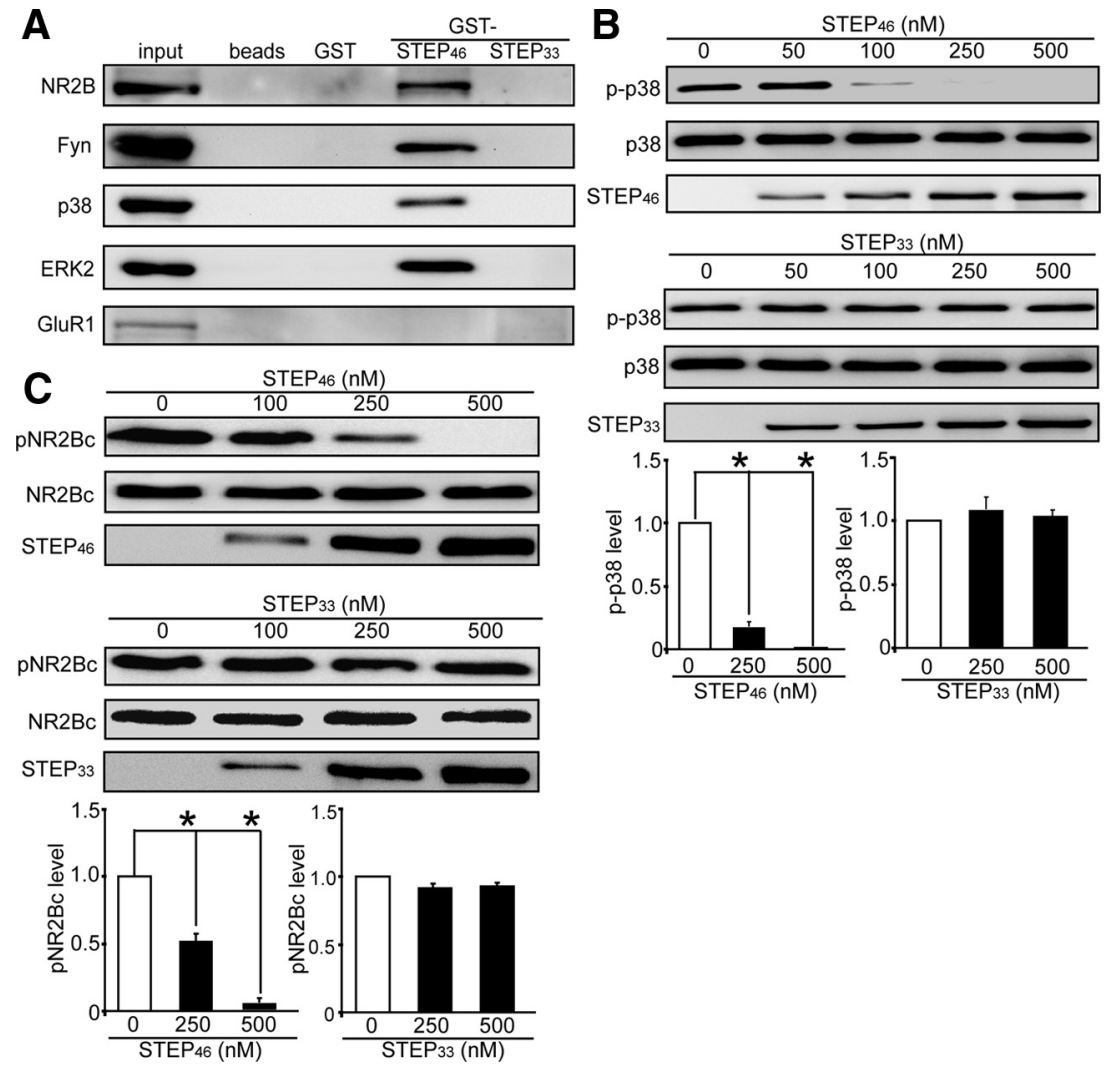

Figure 5. STEP 33 does not interact with STEP substrates. $A$, The substrate-trapping (C to $S)$ mutant of STEP ${ }_{46}$ or STEP $(10 \mu \mathrm{g})$ were coupled to glutathione Sepharose beads and incubated with rat brain homogenates $(100 \mu \mathrm{g})$. Bound proteins were immunoblotted with indicated antibodies. GST protein and glutathione Sepharose beads were used as negative controls. Representative blot was shown from three independent experiments. $\boldsymbol{B}, \mathrm{p}$-p38 (10 ng) was incubated with STEP ${ }_{33}$ or STEP 46 at the indicated concentrations and blotted with phospho-p38, total p38, or STEP antibodies. p-p38 levels were normalized to total p38 ${ }^{*} p<0.01$, one-way ANOVA with post hoc Tukey's test; $n=3$ ). C, GST-NR2BC was phosphorylated by active Fyn, incubated with $\mathrm{STEP}_{33}$ or $\mathrm{STEP}_{46}$ at the indicated concentrations, and blotted with pNR2B $\left(\mathrm{pY}{ }^{1472}\right)$, total NR2B, or STEP antibodies. pNR2B levels were normalized to total NR2B $\left({ }^{*} p<0.01\right.$, one-way ANOVA with post hoc Tukey's test; $n=3$ ).

$\operatorname{STEP}_{33}(95.4 \pm 8.5$ and $95.6 \pm 7.4 \%$ of TAT-myc-treated control, $p>0.05)$.

To confirm these results, an immunocytochemical approach was used (Fig. 6B). Cortical neurons (DIV 21) were treated with TAT-STEP $_{46}$ or TAT-STEP $33(2 \mu \mathrm{M})$ for $30 \mathrm{~min}$ and then stained using C-terminus anti-NR1 and anti-synapsin I antibodies. Addition of TAT-STEP ${ }_{46}$ led to a significant decrease of surface NR1 puncta (13.4 $\pm 1.2 \%$ compared with $18.4 \pm 1.8 \%$ for control; $p<$ $0.01)$. However, both TAT-STEP 33 and TAT-myc failed to reduce NR1 surface expression $(18.1 \pm 1.2$ and $18.2 \pm 1.6 \%$, respectively, compared with control $18.4 \pm 1.8 \% ; p>0.05)$. These data indicate that cleavage of $\mathrm{STEP}_{61}$ to $\mathrm{STEP}_{33}$ likely abrogates the ability of STEP to promote endocytosis of NMDARs.

\section{TAT-STEP peptide prevents cleavage}

of endogenous STEP and is neuroprotective in cortical cultures

Because extrasynaptic activation of NMDARs induced calpaindependent cleavage of STEP 61 and was neurotoxic, we wanted to determine whether selective inhibition of STEP cleavage might be neuroprotective. To this end, a 16 aa peptide was synthesized that spanned the cleavage site and was fused with a TAT peptide. We first tested whether the TAT-STEP peptide reduced STEP cleavage in an in vitro assay with active calpain 1 (Fig. 7A). There was a significant dose-dependent reduction of cleavage in the presence of the TAT-STEP peptide. At a concentration of $2.0 \mu \mathrm{M}$, the peptide almost completely blocked calpainmediated cleavage of STEP $(91.0 \pm 5.5 \%$ compared with no peptide control, $2.14 \pm$ $2.6 \% ; p<0.01)$.

The TAT-STEP peptide was then tested for its ability to block glutamatemediated $\mathrm{STEP}_{33}$ production in neurons. Cortical neurons were incubated with different concentrations of TAT-STEP peptide for $30 \mathrm{~min}$, followed by glutamate stimulation $(100 \mu \mathrm{M})$ for $1 \mathrm{~h}$. Treatment with the TAT-STEP peptide resulted in a dose-dependent inhibition of glutamateinduced cleavage of STEP $_{61}$ (production of $\mathrm{STEP}_{33}$ was $213.6 \pm 6.3,172.0 \pm 13.2$, and $149.8 \pm 5.1 \%$, for 1,2 , and $4 \mu \mathrm{M}$, respectively, compared with no peptide control, $268.8 \pm 14.4 \% ; p<0.01$ ) (Fig. $7 B$ ). These results indicated that the glutamate-mediated production of STEP $_{33}$ was significantly reduced by the TAT-STEP peptide.

These findings raised the possibility that the TAT-STEP peptide might be neuroprotective. To test this prediction, extrasynaptic stimulation was performed on cortical neurons preincubated with the TAT-STEP peptide or TAT-myc control $(4 \mu \mathrm{M})$. We used both $\mathrm{LDH}$ release and the MAP2 assay to test for cytotoxicity and cell viability after extrasynaptic stimulation. Both assays showed that the TATSTEP peptide provided significant neuroprotection against extrasynaptic-induced cell death. Treatment with this peptide reduced $\mathrm{LDH}$ release (LDH release; TATSTEP peptide pretreatment, $313.1 \pm 21.0 \%$ vs extrasynaptic stimulation alone, $457.6 \pm 21.1 \%$ of control; $p<0.01$ ) (Fig. 7C). As a control, calpeptin $(10 \mu \mathrm{M})$ also showed significant neuroprotection against extrasynaptic stimulation (calpeptin, $233.8 \pm$ $15.1 \%$ vs extrasynaptic stimulation alone, $457.6 \pm 21.1 \%$; $p<$ 0.01 ). In contrast, TAT-myc was not neuroprotective (TATmyc, $450.0 \pm 26.1 \%$ vs extrasynaptic stimulation alone, $457.6 \pm$ $21.1 \% ; p>0.05$ ). The MAP2 assay produced similar results (Fig. $7 D)$. Extrasynaptic stimulation again resulted in a significant loss of MAP2 staining $(60.7 \pm 5.8 \%$ of control, $p<0.01)$. However, preincubation with the TAT-STEP peptide rescued neurons from cell death (TAT-STEP peptide, $88.1 \pm 5.6 \%$ vs extrasynaptic stimulation alone, $60.7 \pm 5.8 \% ; p<0.01$ ). Inhibition of calpain by calpeptin was also neuroprotective (calpeptin, $90.6 \pm$ $2.8 \%$ vs extrasynaptic stimulation alone, $60.7 \pm 5.8 \% ; p<0.01$ ), whereas pretreatment with the TAT-myc peptide failed to protect neuronal death (TAT-myc, $64.4 \pm 3.3 \%$ vs extrasynaptic stimulation alone, $60.7 \pm 5.8 \% ; p>0.05)$.

We also visualized the protective effects of by the TAT-STEP peptide by looking at nuclear morphology during extrasynaptic stimulation. Control neurons showed normal diffuse staining of the nucleus, indicating good viability. Extrasynaptic stimulation induced significant neuronal death as identified by the morphological changes associated with apoptosis (e.g., chromatin con- 
densation, nuclear condensation, and segmentation) (viability, $79.4 \pm 4.1 \%$ of control; $p<0.05$ ), whereas in the presence of $4 \mu \mathrm{M}$ TAT-STEP peptide, neuronal death was significantly blocked (viability, $97.8 \pm 3.5 \%$ compared with no peptide, $79.4 \pm 4.1 \%$; $p<0.01$ ) (Fig. $7 E$ ).

One possibility was that the neuroprotective effects of the TAT-STEP peptide were attributable to an inhibition of NMDAR activity. We therefore determined whether the peptide reduced synaptic NMDAR function by performing whole-cell recordings of hippocampal slices. We measured the ratio of the amplitude of NMDAR-mediated EPSCs (NMDA EPSCs) to that of $\mathrm{GABA}_{\mathrm{A}}$ receptor-mediated IPSCs (GABA IPSCs) $_{\mathrm{A}}$ of CA1 neurons in control $(0.278 \pm 0.048$; $n=6)$, TAT-STEP peptide $(0.369 \pm$ $0.048 ; n=11)$, and TAT-Myc $(0.303 \pm$ $0.053 ; n=5)$ treated neurons. Intracellular microinjection of the TAT-STEP peptide did not alter synaptic NMDAR activity $\left(F_{(2,19)}=0.915 ; p>0.05\right)$ (supplemental Fig. 3, available at www. jneurosci.org as supplemental material). These results demonstrated that the neuroprotective effects of TAT-STEP peptide after extrasynaptic NMDAR stimulation were not attributable to inhibition of NMDAR activity.

In addition, we confirmed that TATSTEP peptide did not affect ERK activation with synaptic stimulation. Cortical neurons were preincubated with TAT-STEP peptide $(4 \mu \mathrm{M})$, followed by synaptic stimulation. pERK levels were not affected by this peptide $(p>0.05)$ (supplemental Fig. 4, available at www.jneurosci.org as supplemental material).

\section{TAT-STEP peptide is neuroprotective in the OGD model}

To further assess the neuroprotective effects of blocking calpaindependent cleavage of STEP $_{61}$, we evaluated the TAT-STEP peptide for its ability to protect corticostriatal slices from the excitotoxic effects of OGD (Zhou and Baudry, 2006). Rat corticostriatal slices were treated with the TAT-STEP peptide, a TATmyc control, or calpeptin for $30 \mathrm{~min}$ before OGD, followed by reoxygenation (Fig. $8 \mathrm{~A}$ ). OGD alone induced a significant production of $\mathrm{STEP}_{33}$ (Fig. 8 A, middle) $(570.3 \pm 29.4 \%$ of control; $p<0.01)$. Preincubation with the TAT-STEP peptide ( 1 or $4 \mu \mathrm{M})$ significantly reduced the production of $\mathrm{STEP}_{33}$ after OGD (444.8 \pm 21.5 and $278.2 \pm 28.0 \%$ compared with no peptide control; $p<0.01$ ). The peptide appeared selective in its inhibition, because calpain-dependent cleavage of fodrin remained unaffected even at the highest TAT-STEP concentration used. In comparison, calpeptin $(10 \mu \mathrm{M})$ reduced the OGD-induced production of $\mathrm{STEP}_{33}$ (calpeptin, 76.8 $\pm 5.6 \%$ vs no peptide control, $570.3 \pm 29.4 \% ; p<0.01$ ), as well as fodrin cleavage (calpeptin, $68.6 \pm 9.7 \%$ vs no peptide control, $366.5 \pm 17.5 \% ; p<0.01)$. The TAT-myc $(4 \mu \mathrm{M})$ control had no effect on STEP 33 production after OGD (TAT-myc, $585.8 \pm 16.7 \%$ vs no peptide control, $570.3 \pm 29.4 \% ; p>0.05)$.

We also tested whether the blockade of STEP $_{61}$ cleavage might
B

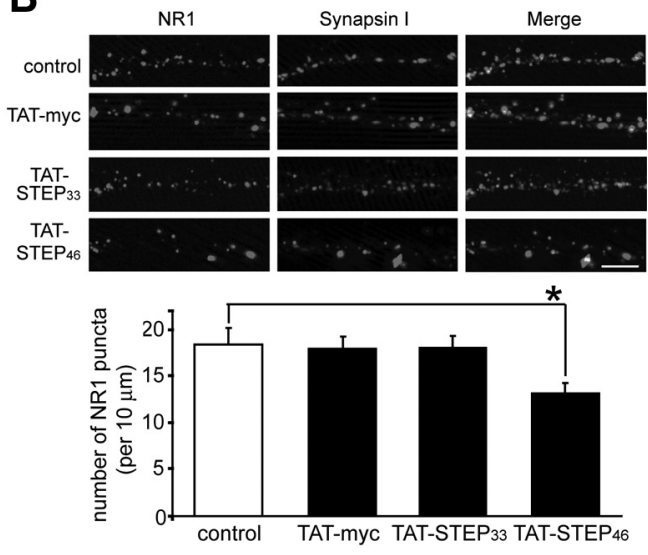

suppress the phosphorylation of p38 at $\mathrm{Thr}^{180} / \mathrm{Tyr}^{182}$ (Fig. $8 A$, bottom). In agreement with previous studies (Tabakman et al., 2005; Guo and Bhat, 2007), OGD stimulation by itself led to significant increase of phospho-p38 (499.3 $\pm 20.4 \%$ of control; $p<0.01$ ). Addition of TAT-STEP peptide ( 1 or $4 \mu \mathrm{M})$ significantly reduced the phosphorylation of p38 $(1 \mu \mathrm{M}, 358.4 \pm 13.8 \%$; $4 \mu \mathrm{M}, 291.7 \pm 10.7 \%$ vs no peptide control, $499.3 \pm 20.4 \%$; $p<$ $0.01)$ after OGD. Calpeptin also significantly reduced phosphorylation of p38 (calpeptin, $222.6 \pm 13.6 \%$ vs no peptide control, $499.3 \pm 20.4 \% ; p<0.01$ ). In contrast, TAT-myc had no significant effect on p 38 phosphorylation (TAT-myc, $497.5 \pm 14.7 \%$ vs no peptide control, $499.3 \pm 20.4 \%$; $p>0.05)$. We confirmed this finding in cortical neurons treated with glutamate. Glutamate at $100 \mu \mathrm{M}$ induced significant production of $\mathrm{STEP}_{33}(314.7 \pm$ $16.1 \%$ of control; $p<0.01)$ and activation of p38 (378.0 $\pm 22.4 \%$ of control; $p<0.01$ ) (supplemental Fig. 5, available at www. jneurosci.org as supplemental material). Preincubation with TAT-STEP peptide $(4 \mu \mathrm{M})$ significantly blocked STEP cleavage (174.5 $\pm 11.2 \%$ compared with no peptide; $314.7 \pm 16.1 \%$; $p<$ $0.01)$ and p38 activation (242.9 $\pm 9.2 \%$ compared with no peptide; $378.0 \pm 22.4 \% ; p<0.01)$, whereas TAT-myc peptide $(4$ $\mu \mathrm{M})$ failed to affect STEP cleavage and p38 activation $(p>0.05)$ (supplemental Fig. 5, available at www.jneurosci.org as supplemental material).

We then measured $\mathrm{LDH}$ release to determine whether the reduction of STEP $_{61}$ cleavage by TAT-STEP peptide was neuroprotective (Fig. $8 \mathrm{~B}$ ). OGD treatment alone induced a significant release of $\mathrm{LDH}(363.7 \pm 15.6 \%$ of control; $p<0.01)$, whereas pretreatment with the TAT-STEP peptide $(4 \mu \mathrm{M})$ significantly 
A

calpain 1

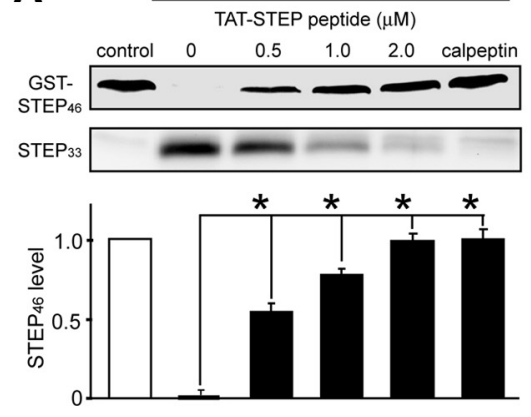

C

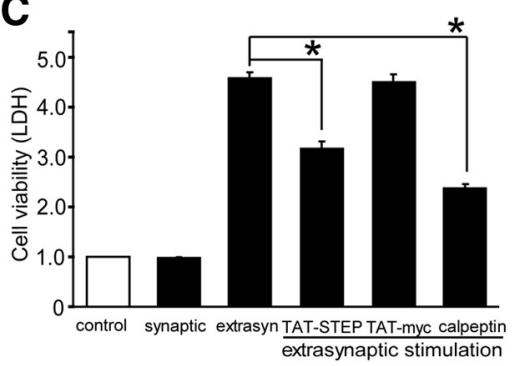

\section{E}
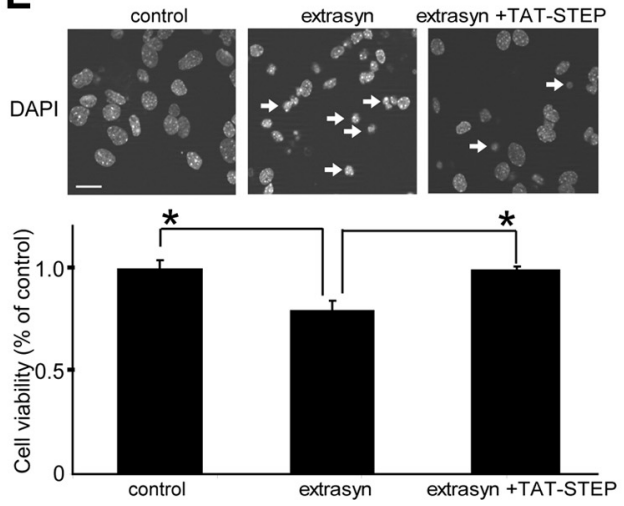

Figure 7. TAT-STEP peptide is neuroprotective against glutamate excitotoxicity. A, GST-STEP 46 was digested with calpain 1 in the presence of TAT-STEP peptide at the indicated concentrations. Calpeptin $(10 \mu \mathrm{M})$ served as a control. Uncleaved STEP was normalized to no treatment control $\left({ }^{*} p<0.01\right.$, one-way ANOVA with post hoc Tukey's test; $n=3$ ). $B$, Cortical neurons were pretreated with TAT-STEP peptide or calpeptin $(10 \mu \mathrm{M})$, followed by glutamate stimulation for $1 \mathrm{~h}$. Total cell lysates were blotted with antibodies against STEP and ERK2. Production of STEP ${ }_{33}$ was normalized to total ERK2 levels $\left({ }^{*} p<0.01\right.$, one-way ANOVA with post hoc Tukey's test; $n=3$ ). C, Cell cytotoxicity was assessed by LDH release after synaptic or extrasynaptic stimulations. TAT-STEP peptide, TAT-myc, or calpeptin was preincubated as indicated before extrasynaptic stimulation ( ${ }^{*} p<0.01$, Student's $t$ test; $\left.n=3\right)$. $\boldsymbol{D}$, Cortical cultures were treated as in $\boldsymbol{C}$, and cell viability was measured by MAP2 staining ( ${ }^{*} p<0.01$, Student's $t$ test; $n=3$ ). $E$, Cell viability was quantified using DAPI staining. Arrows indicate injured or dead neurons, which show nuclear morphological changes (e.g., chromatin condensation, nuclear condensation, and segmentation). At least 250 randomly selected cells were counted for each stimulation $\left({ }^{*} p<0.01\right.$, Student's $t$ test). Scale bar, $10 \mu \mathrm{m}$.

reduced $\mathrm{LDH}$ release $(1 \mu \mathrm{M}, 267.9 \pm 17.4 \% ; 4 \mu \mathrm{M}, 189.4 \pm 10.9 \%$ vs no peptide control, $363.7 \pm 15.6 \%$; $p<0.01$ ). Calpeptin reduced LDH release to a similar extent as the TAT-STEP peptide (calpeptin, $175.0 \pm 12.0 \%$ vs no peptide control, $363.7 \pm 15.6 \%$; $p<0.01)$ after OGD. In contrast, TAT-myc had no significant effect on OGD-induced LDH release (TAT-myc, $362.3 \pm 20.6 \%$ vs no peptide control, $363.7 \pm 15.6 \%$; $p>0.05$ ).

To further examine whether reduction of STEP $_{61}$ cleavage affected p38 signaling, we examined Bax, a well established target of p38 during apoptosis (Fig. 8C) (Ghatan et al., 2000; GomezLazaro et al., 2008). After excitotoxic stimulation, Bax translocates from the cytosol to mitochondrial fractions (Hsu et al., 1997; Cao et al., 2001). In agreement with previous studies, OGD alone led to the translocation of Bax to mitochondria (cytosol,
$69.1 \pm 3.4 \%$ of control, $p<0.01$; mitochondria, $158.8 \pm 7.8 \%$ of control, $p<$ 0.01). TAT-STEP peptide significantly reduced the translocation of Bax (cytosol, TAT-STEP peptide, $85.1 \pm 4.8 \%$ vs OGD, $69.1 \pm 3.4 \%, p<0.01$; mitochondria, TAT-STEP peptide, $124.4 \pm 4.8 \%$ vs OGD, $158.8 \pm 7.8 \%, p<0.01)$. Blockade of STEP $_{61}$ cleavage by calpeptin $(10 \mu \mathrm{M})$ also reduced the OGD-induced Bax translocation (cytosol, $88.5 \pm 2.8 \%$ vs OGD, $69.1 \pm 3.4 \%, p<0.01$; mitochondria, $113.4 \pm 12.1 \%$ vs OGD, $158.8 \pm 7.8 \%$, $p<0.01)$. The control TAT-myc peptide failed to block Bax translocation (cytosol, $70.1 \pm 5.7 \%, p>0.05$; mitochondria, $163.1 \pm 7.3 \%, p>0.05)$. Together, these results demonstrated that the TAT-STEP peptide reduced cleavage of endogenous $\mathrm{STEP}_{61}$, protected neurons from OGDmediated excitotoxic death, and attenuated Bax translocation to mitochondria.

Based on these results, we predicted that STEP deficiency in $\mathrm{KO}$ mice would affect p38 signaling. First we determined basal levels of p-p38 and p38 in STEP KO versus WT mice. We observed a significant increase of p-p38 levels in STEP KO mice $(137.6 \pm 4.7 \%$ of control; $p<0.01)$, whereas total p38 levels remained constant ( $p>0.05)$ (supplemental Fig. 6, available at www.jneurosci.org as supplemental material). We next investigated whether STEP KO mice would show differential excitotoxicity during OGD stimulation compared with WT littermates. Both WT and KO slices showed similar LDH production levels under basal conditions (WT, $100.4 \pm 1.2 \%$; KO, $107.7 \pm 7.0 ; p>0.05)$ (Fig. 8D). However, KO slices showed greater cell toxicity than WT slices during OGD insult (WT, $181.1 \pm 11.6 \%$; KO, $259.5 \pm 20.6 ; p<0.01)$. These data indicated that, in the absence of STEP, there was a significant increase in OGDmediated cell death.

\section{Discussion}

The present study was initiated in an effort to resolve an apparent paradox in the function of the STEP family of phosphatases. STEP ${ }_{61}$ regulates the activity of both ERK1/2 and p38, proteins with very different, if not opposing, effects on cellular function. Our hypothesis was that $\mathrm{STEP}_{61}$ would need to be tightly regulated to function both as a regulator of synaptic strengthening and of neuronal cell death. A striking finding in the present study is the differential posttranslational modification of $\mathrm{STEP}_{61}$ depending on the type of NMDAR stimulation. Synaptic stimulation of NMDARs leads to $\mathrm{STEP}_{61}$ ubiquitination, whereas extrasynaptic stimulation leads to $\mathrm{STEP}_{61}$ proteolysis. In both cases, the net effect is a reduction of $\mathrm{STEP}_{61}$ levels. We went on to confirm that synaptic stimulation leads to phosphorylation of ERK1/2 (Ivanov et al., 2006), whereas extrasynaptic stimulation leads to phosphorylation of p38. Importantly, 
reducing proteolysis of $\mathrm{STEP}_{61}$ is neuroprotective in two different models of excitotoxic cell death.

Stimulation of NMDARs can have opposing effects on neuronal survival or cell death (Hardingham and Bading, 2003). Activation of synaptic NMDARs is coupled to CREB activation and cell survival, whereas stimulation of extrasynaptic NMDARs turns off the CREB pathway (Hardingham et al., 2002; Soriano and Hardingham, 2007; Mulholland et al., 2008). Despite considerable progress in the analysis of different signaling pathways selectively activated by synaptic or extrasynaptic NMDARs (Hardingham et al., 2002; Zhang et al., 2007; Papadia et al., 2008; Wahl et al., 2009), the underlying mechanisms for such marked differences in cellular responses have not been identified. The findings presented here demonstrate that the differential regulation of STEP $_{61}$ plays an important role in this process.

Calpain cleavage of STEP $_{61}$ was selectively invoked by extrasynaptic stimulation and this correlated directly with $\mathrm{p} 38$ activation. Calpain has been widely implicated in neurotoxicity (Liu et al., 2008), and calpain inhibitors have been suggested to be neuroprotective (Wells and Bihovsky, 1998). Interestingly, calpain has also been suggested to be important for synaptic remodeling processes that underlie long-term memory (Lynch and Gleichman, 2007; Lynch et al., 2007). Thus, whereas excitotoxic extrasynaptic activation of calpain may have deleterious effects involving STEP $_{61}$ and p38, normal glutamatergic neurotransmission may induce calpain-dependent pathways not involving STEP $_{61}$ cleavage.

Calpain has been demonstrated to associate with Cdk5 (Kusakawa et al., 2000), and a recent study showed that Cdk5 enhanced calpain activity (Hawasli et al., 2007), allowing us to test our model in an independent system. Given that Cdk5 increased STEP $_{61}$ proteolysis and that Cdk5 cKO mice have elevated synaptic STEP ${ }_{61}$ with concomitant increase in $\mathrm{pY}^{1472}$, our results provide additional evidence that Cdk5 enhances calpain activity on its substrates that may be involved in both normal neuronal function as well as harmful pathways (Hawasli et al., 2007). Cdk5 binds NR2B and links calpain to the receptor, which, like the cofactor of Cdk5, p35, also serves as a calpain substrate, whereas NR2B serves as a substrate for both $\mathrm{STEP}_{61}$ and calpain. Thus, one possibility is that $\mathrm{STEP}_{61}$ is integrated into an NMDAR/calpain/Cdk5/STEP ${ }_{61}$ signaling complex.

We found that the calpain cleavage site in $\mathrm{STEP}_{61}$ resides within the substrate-binding domain of STEP (KIM domain). Moreover, the cleaved product $\left(\mathrm{STEP}_{33}\right)$ no longer interacts with four known STEP substrates despite an intact catalytic domain that retains the ability to dephosphorylate the small substrate molecule para-nitrophenylphosphate (pNPP) (Braithwaite et al., 2008). This could be attributed to the ability of pNPP to fit within the catalytic pocket without relying on binding sites outside of the phosphatase domain to stabilize its interaction with STEP. It is possible that the $\mathrm{STEP}_{33}$ has new substrates, similar to other calpain cleavage products of several proteins (Frangioni et al., 1993; Hou et al., 2006). We attempted to address this issue by comparing the proteins associated with recombinant substrate-trapping variants of both $\mathrm{STEP}_{46}$ and $\mathrm{STEP}_{33}$. These experiments did not reveal novel proteins binding to $\mathrm{STEP}_{33}$ compared with $\mathrm{STEP}_{46}$, although more rigorous experiments may be necessary to resolve this issue.

Previously we demonstrated that $\mathrm{STEP}_{61}$ is phosphorylated at $\mathrm{Ser}^{221}$ by PKA and that this phosphorylation is regulated by dopamine (induces phosphorylation) and glutamate (induces dephosphorylation) (Paul et al., 2000, 2003). Similar to the calpain cleavage site, the phosphorylation site resides within the KIM domain and has been shown to negatively affect substrate binding, thereby prolonging substrate activity (Paul et al., 2003). Phosphorylation of various proteins by PKA and other kinases has been shown to modulate their cleavage by calpain (Wang et al., 2005; Johnson, 2006). Thus, it is interesting to consider that STEP degradation via calpain may be regulated under physiological as well as excitotoxic conditions by dopamine signaling.

Excitotoxic stimulation of cortical cultures commonly leads to neuronal cell death. Excessive glutamate release has been implicated in a number of CNS disorders, with cell death occurring, in part, through overactivation of NMDARs (Chen et al., 2008; Schumann et al., 2008; Xu et al., 2008). Several studies have shown that, during epileptic or ischemic insults, NMDARs are tyrosine phosphorylated by members of the Src-family kinases (SFKs), which subsequently potentiates calcium-mediated sig- 
naling through NMDARs (Cheung et al., 2000; Takagi et al., 2003; Huo et al., 2006). Moreover, inhibition of NMDARs or SFKs protects neurons from cell death in these models of excitotoxicity (Paul et al., 2001; Lennmyr et al., 2004; Gee et al., 2006). We show that extrasynaptic stimulation of NMDARs promotes calpain cleavage and inactivation of $\mathrm{STEP}_{61}$, which normally dephosphorylates NR2B. Therefore, our findings provide an additional mechanism whereby tyrosine phosphorylation of NMDARs is enhanced after excitotoxicity.

STEP $_{61}$ normally opposes the development of synaptic strengthening by inactivating key signaling proteins in the postsynaptic terminal. $\mathrm{STEP}_{61}$ dephosphorylates a regulatory tyrosine on ERK1/2, p38, and Fyn tyrosine kinase, thereby inactivating them (Nguyen et al., 2002; Muñoz et al., 2003; Paul et al., 2003). In addition, STEP $_{61}$ dephosphorylates the $\operatorname{tyr}^{1472}$ on the NR2B subunit of the NMDAR, which promotes internalization of the NMDAR complex (Snyder et al., 2005). $\mathrm{Tyr}^{1472}$ is also a target for Fyn phosphorylation, which leads to exocytosis of NMDAR complexes to neuronal surfaces (Dunah et al., 2004; Hallett et al., 2006). Thus, STEP ${ }_{61}$ promotes NMDAR internalization by both inactivating Fyn and dephosphorylating NR2B Tyr ${ }^{1472}$.

The present study shows that $\mathrm{STEP}_{33}$ was unable to promote endocytosis of the NMDARs (NR1/NR2B), in contrast to wildtype $\mathrm{STEP}_{61}$. As mentioned previously, several studies have implicated overactive NMDARs and Src-family members as a mechanism that promotes neuronal cell death. Thus, proteolytic cleavage of STEP $_{61}$ could partially explain these findings, because loss of STEP $_{61}$ activity after extrasynaptic NMDAR stimulation would increase surface expression of NMDAR complexes and increase Fyn activity. In support of our hypothesis, a previous study showed that ischemic challenge resulted in increased phosphorylation at $\mathrm{Tyr}^{1472}$ of NR2B subunit, suggesting possible changes in the activity and/or distribution of protein tyrosine phosphatases (Besshoh et al., 2005). Moreover, our data from the STEP KO mice support this conclusion, because there is a significant increase in OGD-mediated cell death in the absence of STEP.

To test this hypothesis, we developed a tissue diffusible interfering peptide that selectively inhibited calpain-mediated proteolysis of $\mathrm{STEP}_{61}$. This novel inhibitor proved neuroprotective by reducing neural death caused by excitotoxicity in cortical cultures or OGD in cortical slices. Previous studies have shown that glutamate-induced excitotoxicity relies heavily on NMDARs and involves activation of p38. Rho GTPase (Semenova et al., 2007) and nitric oxide (NO) (Bossy-Wetzel et al., 2004; Izumi et al., 2008) have been shown to be upstream of p38 signaling, which link calcium influx with the activation of the neuronal p38 and account for the subsequent cell death. p38 inhibitors (Legos et al., 2002), inhibition of Rho (Semenova et al., 2007), and uncoupling of neural NO synthase activation from the NMDARs (Aarts et al., 2002; Soriano et al., 2008) are effective in rescuing neurons from glutamate excitotoxicity. It will be important to determine whether STEP plays a role in modulating Rho and NO signaling.

A recent study examined the selective vulnerability of GABAergic hilar interneurons to pilocarpine-induced status epilepticus and suggested that the loss of these neurons was attributable to activation of STEP $_{61}$ and inhibition of ERK1/2 prosurvival pathways (Choi et al., 2007). Here, we extended this previous work, which did not differentiate between synaptic and extrasynaptic stimulation of NMDARs, to support a model in which STEP $_{61}$ modulates both prosurvival and proapoptotic pathways depending on the type of input. Synaptic stimulation of
NMDARs leads to ubiquitination and degradation of STEP ${ }_{61}$ and prolongation of ERK1/2 prosurvival/synaptic plasticity pathways. Extrasynaptic stimulation leads to a selective calpain-mediated cleavage and loss of STEP $_{61}$ activity, with an upregulation of p-p38 and entry into apoptotic pathways. Although the high STEP levels in hilar interneurons seemed to predispose them to status epilepticus induced cell death, we noted in the previous study that another region expressing high levels of STEP, area CA2, was not similarly predisposed. It is possible that modulatory inputs selectively promote or dampen the cleavage of STEP and thereby alter the susceptibility of the cells of the region to excitotoxicity. In light of the current findings, it would be interesting to reexamine the pilocarpine-induced status epilepticus model and determine whether vulnerable hilar interneurons are lost attributable to $\mathrm{STEP}_{61}$ cleavage and activation of p38 apoptotic pathways.

In conclusion, we have addressed a mechanism by which ERK1/2 and p38 are differentially regulated after glutamate stimulation of synaptic and extrasynaptic NMDARs. The tyrosine phosphatase STEP $_{61}$ plays a critical role in this process. Synaptic and extrasynaptic NMDAR stimulation promotes the degradation of $\mathrm{STEP}_{61}$ by either ubiquitination or calpain-mediated cleavage of $\mathrm{STEP}_{61}$, which facilitates the activation of either ERK1/2 or p38, respectively. Because reduction of $\mathrm{STEP}_{61}$ proteolysis proved neuroprotective to excitotoxic stimulation, our findings may have therapeutic value against excitotoxic insults within the CNS.

\section{References}

Aarts M, Liu Y, Liu L, Besshoh S, Arundine M, Gurd JW, Wang YT, Salter MW, Tymianski M (2002) Treatment of ischemic brain damage by perturbing NMDA receptor- PSD-95 protein interactions. Science 298:846-850.

Arundine M, Tymianski M (2003) Molecular mechanisms of calciumdependent neurodegeneration in excitotoxicity. Cell Calcium 34:325-337.

Bano D, Young KW, Guerin CJ, Lefeuvre R, Rothwell NJ, Naldini L, Rizzuto R, Carafoli E, Nicotera P (2005) Cleavage of the plasma membrane $\mathrm{Na}^{+} / \mathrm{Ca}^{2+}$ exchanger in excitotoxicity. Cell 120:275-285.

Besshoh S, Bawa D, Teves L, Wallace MC, Gurd JW (2005) Increased phosphorylation and redistribution of NMDA receptors between synaptic lipid rafts and post-synaptic densities following transient global ischemia in the rat brain. J Neurochem 93:186-194.

Boland B, Campbell V (2003) Beta-amyloid (1-40)-induced apoptosis of cultured cortical neurones involves calpain-mediated cleavage of polyADP-ribose polymerase. Neurobiol Aging 24:179-186.

Bossy-Wetzel E, Talantova MV, Lee WD, Schölzke MN, Harrop A, Mathews E, Götz T, Han J, Ellisman MH, Perkins GA, Lipton SA (2004) Crosstalk between nitric oxide and zinc pathways to neuronal cell death involving mitochondrial dysfunction and p38-activated $\mathrm{K}^{+}$channels. Neuron 41:351-365.

Boulanger LM, Lombroso PJ, Raghunathan A, During MJ, Wahle P, Naegele JR (1995) Cellular and molecular characterization of a brain-enriched protein tyrosine phosphatase. J Neurosci 15:1532-1544.

Braithwaite SP, Paul S, Nairn AC, Lombroso PJ (2006) Synaptic plasticity: one STEP at a time. Trends Neurosci 29:452-458.

Braithwaite SP, Xu J, Leung J, Urfer R, Nikolich K, Oksenberg D, Lombroso PJ, Shamloo M (2008) Expression and function of striatal enriched protein tyrosine phosphatase is profoundly altered in cerebral ischemia. Eur J Neurosci 27:2444-2452.

Brooke SM, Bliss TM, Franklin LR, Sapolsky RM (1999) Quantification of neuron survival in monolayer cultures using an enzyme-linked immunosorbent assay approach, rather than by cell counting. Neurosci Lett 267:21-24.

Bult A, Zhao F, Dirkx R Jr, Sharma E, Lukacsi E, Solimena M, Naegele JR, Lombroso PJ (1996) STEP61: a member of a family of brain-enriched PTPs is localized to the endoplasmic reticulum. J Neurosci 16:7821-7831. Cao G, Minami M, Pei W, Yan C, Chen D, O’Horo C, Graham SH, Chen J 
(2001) Intracellular Bax translocation after transient cerebral ischemia: implications for a role of the mitochondrial apoptotic signaling pathway in ischemic neuronal death. J Cereb Blood Flow Metab 21:321-333.

Carrier RL, Ma TC, Obrietan K, Hoyt KR (2006) A sensitive and selective assay of neuronal degeneration in cell culture. J Neurosci Methods 154:239-244.

Chen M, Lu TJ, Chen XJ, Zhou Y, Chen Q, Feng XY, Xu L, Duan WH, Xiong ZQ (2008) Differential roles of NMDA receptor subtypes in ischemic neuronal cell death and ischemic tolerance. Stroke 39:3042-3048.

Cheung HH, Takagi N, Teves L, Logan R, Wallace MC, Gurd JW (2000) Altered association of protein tyrosine kinases with postsynaptic densities after transient cerebral ischemia in the rat brain. J Cereb Blood Flow Metab 20:505-512.

Choi YS, Lin SL, Lee B, Kurup P, Cho HY, Naegele JR, Lombroso PJ, Obrietan K (2007) Status Epilepticus-induced somatostatinergic hilar interneuron degeneration is regulated by striatal enriched protein tyrosine phosphatase. J Neurosci 27:2999-3009.

Cummings BS, Schnellmann RG (2004) Measurement of cell death in mammalian cells. In: Current protocols in pharmacology, Chap 12, pp 12.8.1-12.8.22. New York: Wiley.

Davies KD, Alvestad RM, Coultrap SJ, Browning MD (2007) alphaCaMKII autophosphorylation levels differ depending on subcellular localization. Brain Res 1158:39-49.

Dunah AW, Sirianni AC, Fienberg AA, Bastia E, Schwarzschild MA, Standaert DG (2004) Dopamine D1-dependent trafficking of striatal $N$-methyl-Daspartate glutamate receptors requires Fyn protein tyrosine kinase but not DARPP-32. Mol Pharmacol 65:121-129.

Frangioni JV, Oda A, Smith M, Salzman EW, Neel BG (1993) Calpaincatalyzed cleavage and subcellular relocation of protein phosphotyrosine phosphatase 1B (PTP-1B) in human platelets. EMBO J 12:4843-4856.

Fujimura M, Morita-Fujimura Y, Murakami K, Kawase M, Chan PH (1998) Cytosolic redistribution of cytochrome $\mathrm{c}$ after transient focal cerebral ischemia in rats. J Cereb Blood Flow Metab 18:1239-1247.

Gardoni F, Picconi B, Ghiglieri V, Polli F, Bagetta V, Bernardi G, Cattabeni F, Di Luca M, Calabresi P (2006) A critical interaction between NR2B and MAGUK in L-DOPA induced dyskinesia. J Neurosci 26:2914-2922.

Gee CE, Benquet P, Raineteau O, Rietschin L, Kirbach SW, Gerber U (2006) NMDA receptors and the differential ischemic vulnerability of hippocampal neurons. Eur J Neurosci 23:2595-2603.

Ghatan S, Larner S, Kinoshita Y, Hetman M, Patel L, Xia Z, Youle RJ, Morrison RS (2000) p38 MAP kinase mediates bax translocation in nitric oxide-induced apoptosis in neurons. J Cell Biol 150:335-347.

Goebel-Goody SM, Davies KD, Alvestad Linger RM, Freund RK, Browning MD (2009) Phospho-regulation of synaptic and extrasynaptic NMDA receptors in adult hippocampal slices. Neuroscience 158:1446-1459.

Gomez-Lazaro M, Galindo MF, Concannon CG, Segura MF, FernandezGomez FJ, Llecha N, Comella JX, Prehn JH, Jordan J (2008) 6-Hydroxydopamine activates the mitochondrial apoptosis pathway through p38 MAPK-mediated, p53-independent activation of Bax and PUMA. J Neurochem 104:1599-1612.

Guo G, Bhat NR (2007) p38alpha MAP kinase mediates hypoxia-induced motor neuron cell death: a potential target of minocycline's neuroprotective action. Neurochem Res 32:2160-2166.

Gurd JW, Bissoon N, Nguyen TH, Lombroso PJ, Rider CC, Beesley PW, Vannucci SJ (1999) Hypoxia-ischemia in perinatal rat brain induces the formation of a low molecular weight isoform of striatal enriched tyrosine phosphatase (STEP). J Neurochem 73:1990-1994.

Hallett PJ, Spoelgen R, Hyman BT, Standaert DG, Dunah AW (2006) Dopamine $\mathrm{D}_{1}$ activation potentiates striatal NMDA receptors by tyrosine phosphorylation-dependent subunit trafficking. J Neurosci 26:4690-4700.

Hardingham GE, Bading H (2003) The Yin and Yang of NMDA receptor signalling. Trends Neurosci 26:81-89.

Hardingham GE, Fukunaga Y, Bading H (2002) Extrasynaptic NMDARs oppose synaptic NMDARs by triggering CREB shut-off and cell death pathways. Nat Neurosci 5:405-414.

Hawasli AH, Bibb JA (2007) Alternative roles for Cdk5 in learning and synaptic plasticity. Biotechnol J 2:941-948.

Hawasli AH, Benavides DR, Nguyen C, Kansy JW, Hayashi K, Chambon P, Greengard P, Powell CM, Cooper DC, Bibb JA (2007) Cyclindependent kinase 5 governs learning and synaptic plasticity via control of NMDAR degradation. Nat Neurosci 10:880-886.
Hou ST, Jiang SX, Desbois A, Huang D, Kelly J, Tessier L, Karchewski L, Kappler J (2006) Calpain-cleaved collapsin response mediator protein-3 induces neuronal death after glutamate toxicity and cerebral ischemia. J Neurosci 26:2241-2249.

Hsu YT, Wolter KG, Youle RJ (1997) Cytosol-to-membrane redistribution of Bax and Bcl-X(L) during apoptosis. Proc Natl Acad Sci U S A 94:3668-3672.

Hu Y, Zhang Y, Venkitaramani DV, Lombroso PJ (2007) Translation of striatal-enriched protein tyrosine phosphatase (STEP) after beta1adrenergic receptor stimulation. J Neurochem 103:531-541.

Huo JZ, Dykstra CM, Gurd JW (2006) Increase in tyrosine phosphorylation of the NMDA receptor following the induction of status epilepticus. Neurosci Lett 401:266-270.

Ivanov A, Pellegrino C, Rama S, Dumalska I, Salyha Y, Ben-Ari Y, Medina I (2006) Opposing role of synaptic and extrasynaptic NMDA receptors in regulation of the extracellular signal-regulated kinases (ERK) activity in cultured rat hippocampal neurons. J Physiol 572:789-798.

Izumi Y, Tokuda K, Zorumski CF (2008) Long-term potentiation inhibition by low-level $\mathrm{N}$-methyl-D-aspartate receptor activation involves calcineurin, nitric oxide, and p38 mitogen-activated protein kinase. Hippocampus 18:258-265.

Johnson GV (2006) Tau phosphorylation and proteolysis: insights and perspectives. J Alzheimers Dis 9:243-250.

Kusakawa G, Saito T, Onuki R, Ishiguro K, Kishimoto T, Hisanaga S (2000) Calpain-dependent proteolytic cleavage of the p35 cyclin-dependent kinase 5 activator to p25. J Biol Chem 275:17166-17172.

Legos JJ, McLaughlin B, Skaper SD, Strijbos PJ, Parsons AA, Aizenman E, Herin GA, Barone FC, Erhardt JA (2002) The selective p38 inhibitor SB-239063 protects primary neurons from mild to moderate excitotoxic injury. Eur J Pharmacol 447:37-42.

Lennmyr F, Ericsson A, Gerwins P, Akterin S, Ahlström H, Terént A (2004) Src family kinase-inhibitor PP2 reduces focal ischemic brain injury. Acta Neurol Scand 110:175-179.

Léveillé F, El Gaamouch F, Gouix E, Lecocq M, Lobner D, Nicole O, Buisson A (2008) Neuronal viability is controlled by a functional relation between synaptic and extrasynaptic NMDA receptors. FASEB J 22:4258-4271.

Lipton P (1999) Ischemic cell death in brain neurons. Physiol Rev 79:1431-1568.

Lipton SA, Rosenberg PA (1994) Excitatory amino acids as a final common pathway for neurologic disorders. N Engl J Med 330:613-622.

Liu J, Liu MC, Wang KK (2008) Calpain in the CNS: from synaptic function to neurotoxicity. Sci Signal 1:re1.

Lombroso PJ, Murdoch G, Lerner M (1991) Molecular characterization of a protein-tyrosine-phosphatase enriched in striatum. Proc Natl Acad Sci U S A 88:7242-7246.

Lombroso PJ, Naegele JR, Sharma E, Lerner M (1993) A protein tyrosine phosphatase expressed within dopaminoceptive neurons of the basal ganglia and related structures. J Neurosci 13:3064-3074.

Lynch DR, Gleichman AJ (2007) Picking up the pieces: the roles of functional remnants of calpain-mediated proteolysis. Neuron 53:317-319.

Lynch G, Rex CS, Gall CM (2007) LTP consolidation: substrates, explanatory power, and functional significance. Neuropharmacology 52:12-23.

Mabuchi T, Kitagawa K, Kuwabara K, Takasawa K, Ohtsuki T, Xia Z, Storm D, Yanagihara T, Hori M, Matsumoto M (2001) Phosphorylation of cAMP response element-binding protein in hippocampal neurons as a protective response after exposure to glutamate in vitro and ischemia in vivo. J Neurosci 21:9204-9213.

Malenka RC, Nicoll RA (1993) NMDA-receptor-dependent synaptic plasticity: multiple forms and mechanisms. Trends Neurosci 16:521-527.

Martel MA, Wyllie DJ, Hardingham GE (2009) In developing hippocampal neurons, NR2B-containing $N$-methyl-D-aspartate receptors (NMDARs) can mediate signaling to neuronal survival and synaptic potentiation, as well as neuronal death. Neuroscience 158:334-343.

Meng L, Mohan R, Kwok BH, Elofsson M, Sin N, Crews CM (1999) Epoxomicin, a potent and selective proteasome inhibitor, exhibits in vivo antiinflammatory activity. Proc Natl Acad Sci U S A 96:10403-10408.

Mulholland PJ, Luong NT, Woodward JJ, Chandler LJ (2008) Brainderived neurotrophic factor activation of extracellular signalregulated kinase is autonomous from the dominant extrasynaptic NMDA receptor extracellular signal-regulated kinase shutoff pathway. Neuroscience 151:419-427. 
Muñoz JJ, Tárrega C, Blanco-Aparicio C, Pulido R (2003) Differential interaction of the tyrosine phosphatases PTP-SL, STEP and HePTP with the mitogen-activated protein kinases ERK1/2 and p38alpha is determined by a kinase specificity sequence and influenced by reducing agents. Biochem J 372:193-201.

Nguyen TH, Paul S, Xu Y, Gurd JW, Lombroso PJ (1999) Calciumdependent cleavage of striatal enriched tyrosine phosphatase (STEP). J Neurochem 73:1995-2001.

Nguyen TH, Liu J, Lombroso PJ (2002) Striatal enriched phosphatase 61 dephosphorylates Fyn at phosphotyrosine 420. J Biol Chem 277:24274-24279.

Oyama T, Goto S, Nishi T, Sato K, Yamada K, Yoshikawa M, Ushio Y (1995) Immunocytochemical localization of the striatal enriched protein tyrosine phosphatase in the rat striatum: a light and electron microscopic study with a complementary DNA-generated polyclonal antibody. Neuroscience 69:869-880.

Papadia S, Soriano FX, Léveillé F, Martel MA, Dakin KA, Hansen HH, Kaindl A, Sifringer M, Fowler J, Stefovska V, McKenzie G, Craigon M, Corriveau R, Ghazal P, Horsburgh K, Yankner BA, Wyllie DJ, Ikonomidou C, Hardingham GE (2008) Synaptic NMDA receptor activity boosts intrinsic antioxidant defenses. Nat Neurosci 11:476-487.

Paul R, Zhang ZG, Eliceiri BP, Jiang Q, Boccia AD, Zhang RL, Chopp M, Cheresh DA (2001) Src deficiency or blockade of Src activity in mice provides cerebral protection following stroke. Nat Med 7:222-227.

Paul S, Snyder GL, Yokakura H, Picciotto MR, Nairn AC, Lombroso PJ (2000) Dopamine/D1 receptor mediates the phosphorylation and inactivation of the protein tyrosine phosphatase, STEP, through a PKAmediated pathway. J Neurosci 20:5630-5638.

Paul S, Nairn AC, Wang P, Lombroso PJ (2003) NMDA-mediated activation of the tyrosine phosphatase STEP regulates the duration of ERK signaling. Nat Neurosci 6:34-42.

Paul S, Olausson P, Venkitaramani DV, Ruchkina I, Moran TD, Tronson N, Mills E, Hakim S, Salter MW, Taylor JR, Lombroso PJ (2007) The striatal-enriched protein tyrosine phosphatase gates long-term potentiation and fear memory in the lateral amygdala. Biol Psychiatry 61:1049-1061.

Proctor WR, Diao L, Freund RK, Browning MD, Wu PH (2006) Synaptic GABAergic and glutamatergic mechanisms underlying alcohol sensitivity in mouse hippocampal neurons. J Physiol 575:145-159.

Schumann J, Alexandrovich GA, Biegon A, Yaka R (2008) Inhibition of NR2B phosphorylation restores alterations in NMDA receptor expression and improves functional recovery following traumatic brain injury in mice. J Neurotrauma 25:945-957.

Semenova MM, Mäki-Hokkonen AM, Cao J, Komarovski V, Forsberg KM, Koistinaho M, Coffey ET, Courtney MJ (2007) Rho mediates calciumdependent activation of p38alpha and subsequent excitotoxic cell death. Nat Neurosci 10:436-443.

Siman R, Baudry M, Lynch G (1984) Brain fodrin: substrate for calpain I, an endogenous calcium-activated protease. Proc Natl Acad Sci U S A 81:3572-3576.

Snyder EM, Nong Y, Almeida CG, Paul S, Moran T, Choi EY, Nairn AC, Salter MW, Lombroso PJ, Gouras GK, Greengard P (2005) Regulation of NMDA receptor trafficking by amyloid-beta. Nat Neurosci 8:1051-1058.
Soriano FX, Hardingham GE (2007) Compartmentalized NMDA receptor signalling to survival and death. J Physiol 584:381-387.

Soriano FX, Martel MA, Papadia S, Vaslin A, Baxter P, Rickman C, Forder J, Tymianski M, Duncan R, Aarts M, Clarke P, Wyllie DJ, Hardingham GE (2008) Specific targeting of pro-death NMDA receptor signals with differing reliance on the NR2B PDZ ligand. J Neurosci 28:10696-10710.

Tabakman R, Jiang H, Shahar I, Arien-Zakay H, Levine RA, Lazarovici P (2005) Neuroprotection by NGF in the PC12 in vitro OGD model: in volvement of mitogen-activated protein kinases and gene expression. Ann N Y Acad Sci 1053:84-96.

Takagi N, Sasakawa K, Besshoh S, Miyake-Takagi K, Takeo S (2003) Transient ischemia enhances tyrosine phosphorylation and binding of the NMDA receptor to the Src homology 2 domain of phosphatidylinositol 3-kinase in the rat hippocampus. J Neurochem 84:67-76.

Tashev R, Moura PJ, Venkitaramani DV, Prosperetti C, Centonze D, Paul S, Lombroso PJ (2009) The tyrosine phosphatase, STEP, regulates longterm potentiation and amphetamine-induced stereotypies in the ventrolateral striatum. Biol Psychiatry 65:637-645.

Vanhoutte P, Bading H (2003) Opposing roles of synaptic and extrasynaptic NMDA receptors in neuronal calcium signalling and BDNF gene regulation. Curr Opin Neurobiol 13:366-371.

Wahl AS, Buchthal B, Rode F, Bomholt SF, Freitag HE, Hardingham GE, Rønn LC, Bading H (2009) Hypoxic/ischemic conditions induce expression of the putative pro-death gene Clcal via activation of extrasynaptic $N$-methyl-D-aspartate receptors. Neuroscience 158:344-352.

Wang H, Guo Z, Wu F, Long F, Cao X, Liu B, Zhu Z, Yao X (2005) PKAmediated protein phosphorylation protects ezrin from calpain I cleavage. Biochem Biophys Res Commun 333:496-501.

Waxman EA, Lynch DR (2005) N-methyl-D-aspartate receptor subtype mediated bidirectional control of p38 mitogen-activated protein kinase. J Biol Chem 280:29322-29333.

Wells GJ, Bihovsky R (1998) Calpain inhibitors as potential treatment for stroke and other neurodegenerative diseases: recent trends and developments. Expert Opin Ther Pat 8:1707-1727.

Xu J, Zhang QG, Li C, Zhang GY (2007) Subtoxic N-methyl-D-aspartate delayed neuronal death in ischemic brain injury through TrkB receptorand calmodulin-mediated PI-3K/Akt pathway activation. Hippocampus 17:525-537.

Xu J, Liu Y, Zhang GY (2008) Neuroprotection of GluR5-containing kainate receptor activation against ischemic brain injury through decreasing tyrosine phosphorylation of $N$-methyl-D-aspartate receptors mediated by Src kinase. J Biol Chem 283:29355-29366.

Zhang SJ, Steijaert MN, Lau D, Schütz G, Delucinge-Vivier C, Descombes P, Bading H (2007) Decoding NMDA receptor signaling: identification of genomic programs specifying neuronal survival and death. Neuron 53:549-562.

Zhang Y, Venkitaramani DV, Gladding CM, Zhang Y, Kurup P, Molnar E, Collingridge GL, Lombroso PJ (2008) The tyrosine phosphatase STEP mediates AMPA receptor endocytosis after metabotropic glutamate receptor stimulation. J Neurosci 28:10561-10566.

Zhou M, Baudry M (2006) Developmental changes in NMDA neurotoxicity reflect developmental changes in subunit composition of NMDA receptors. J Neurosci 26:2956-2963. 